\title{
Trace metals and PAHs in topsoils of the University campus in the megacity of São Paulo, Brazil
}

\author{
CHRISTINE L.M. BOUROTTE ${ }^{1}$, LUCY E. SUGAUARA ${ }^{2}$, MARY R.R. \\ DE MARCHI ${ }^{2}$ and CARLOS E. SOUTO-OLIVEIRA ${ }^{1}$
}

\author{
${ }^{1}$ Instituto de Geociências, Universidade de São Paulo, Rua do Lago, 562, 05508-080 São Paulo, SP, Brazil \\ ${ }^{2}$ Grupo de Estudo em Saúde Ambiental e Contaminantes Orgânicos, Departamento de Química \\ Analítica, Instituto de Química, Universidade Estadual Paulista "Júlio de Mesquisa Filho"/UNESP, \\ Campus Araraquara, Rua Prof. Francisco Degni, 55, 14800-970 Araraquara, SP, Brazil
}

Manuscript received on April 5, 2018; accepted for publication on October 17, 2018

\begin{abstract}
How to cite: BOUROTTE CLM, SUGAUARA LE, MARCHI MRR AND SOUTO-OLIVEIRA CE. 2019. Trace metals and PAHs in topsoils of the University campus in the megacity of São Paulo, Brazil. An Acad Bras Cienc 91: e20180334. DOI 10.1590/0001-3765201920180334.

Abstract: The aim of this study is to discuss the concentration distribution, composition and possible sources of trace metals and 13 PAHs in topsoils of the University campus, in the city of São Paulo, the largest city of South America. Mineralogy and granulometry of topsoils $(0-10 \mathrm{~cm})$ samples, were determined and $\mathrm{As}, \mathrm{Ba}, \mathrm{Cd}, \mathrm{Co}, \mathrm{Cr}, \mathrm{Cu}, \mathrm{Mo}, \mathrm{Ni}, \mathrm{Pb}, \mathrm{Sb}, \mathrm{V}, \mathrm{Zn}, \mathrm{Hg}, \mathrm{Pt}, \mathrm{Pd}$ and PAHs concentrations were quantified in the bulk fraction. The average clay content of soils was $221 \pm 61.8 \mathrm{~g} \mathrm{~kg}^{-1}$ and total carbon was low (mean of $25 \mathrm{~g} \mathrm{~kg}^{-1}$ ). Concentrations of metals were generally lower than the reference value established by the São Paulo State Environmental Agency and other studies in the São Paulo urban area, except for Cd, Ni, Pb, Cr and $\mathrm{Zn}$. The mean concentration of the sum of 13 PAHs was $0.33 \mathrm{mg} \mathrm{kg}^{-1}$ and fluorene, indeno(1,2,3-cd) pyrene, anthracene, pyrene and benzo(ghi)perylene were the most abundant compounds. PAHs and trace metals variability were constrained in PMF analysis and showed an association with exhaust and nonexhaust vehicular emissions. The results also pointed out a spatial pattern in the campus area related to traffic conditions and intensity and terrain slope.
\end{abstract}

Key words: urban topsoils, trace metals, PAHs, PMF.

\section{INTRODUCTION}

The urban environment is a worldwide concern since the concentration distribution and the geochemistry of contaminants in urban environment (atmosphere, dust, soil, water and vegetation) need a better understanding (Wong et al. 2006). According to the United Nations (2014), more than half of the

Correspondence to: Christine Laure Marie Bourotte

E-mail: chrisbourotte@usp.br

ORCid: https://orcid.org/0000-0002-2821-1059 world's population is living in urban areas and is exposed to a complex mixture of pollutants. Soils in urban areas are submitted to intense anthropogenic activities related to civil construction, industrial activities and vehicular traffic that are responsible for their degradation and chemical contamination by direct disposal of contaminant to the soils. Dry and wet atmospheric deposition is also an important source for contaminants in urban soils and street dust (Tanner et al. 2008). Soil pollution by metals and other compounds such as Polycyclic Aromatic 
Hydrocarbons (PAHs) has been described in several studies and different urban contexts principally performed in northern hemisphere (Werkenthin et al. 2014, Orecchio 2010, Nadal et al. 2004, Jensen et al. 2007, Haugland et al. 2008, Mielke et al. 2004, Manta et al. 2002, Madrid et al. 2002, Charlesworth et al. 2011, Alekseenko and Alekseenko 2014) and Asia (Zhang et al. 2006, Zuo et al. 2007, Chung et al. 2007, Ray et al. 2008, Agarwal 2009, Jiang et al. 2009, Liu et al. 2010). In South America, fewer studies have been published in urban areas (Morton et al. 2001, Morcelli et al. 2005, Ribeiro et al. 2012, Figueiredo et al. 2011, Fujiwara et al. 2011, Bourotte et al. 2009, Netto et al. 2006).

Toxic substances such as trace metals or persistent organic pollutants like PAHs in the soil-atmosphere interface are of concern since they accumulate in topsoil horizons and may be re-suspended and inhaled causing risk for human health and ecosystems. Wilcke (2007) also pointed out that PAHs as a complex mixture in topsoils are originated from two main sources: the background condition with a biological component and anthropogenic processes through atmospheric deposition. Since little information exists on the occurrence and distribution of metals and PAHs in Brazilian soils in urban areas, the aim of this study is to discuss the distribution of trace metals and PAHs concentration and their possible sources of topsoils in the campus of the University, a green area of the São Paulo city. To this end descriptive statistics and Positive Matrix Factorization (PMF) analysis, a statistical approach to identify contaminant sources, were performed using spatial variability of PAHs and trace metals concentrations.

\section{MATERIALS AND METHODS}

\section{STUDY AREA AND SAMPLING SITES}

The metropolitan region of São Paulo is the world's fourth largest city and the biggest metropolis in South America. This agglomeration of 21 million inhabitants is in an area of $8,051 \mathrm{~km}^{2}$ of which $18.7 \%$ are in the municipality of São Paulo $\left(23^{\circ} 32\right.$ ' $\left.51^{\prime \prime} \mathrm{S}, 46^{\circ} 38^{\prime} 10^{\prime \prime} \mathrm{W}\right)$. The greater portion $(66 \%)$ of the municipality of São Paulo is an urban area and accounts with a population of 11 million of inhabitants and a fleet of 8.5 million of vehicles, composed of $70.5 \%$ of cars, $13 \%$ of light trucks, $3 \%$ of trucks and buses and $13.5 \%$ of motorcycles (DETRAN 2017). The climate is humid subtropical, with a dry season during winter (June-August) and a wet season during summer (December-February), an annual temperature average of $18.7^{\circ} \mathrm{C}$ and an annual average precipitation of $1410 \mathrm{~mm}$ (IAGUSP 2016).

The sampling site is located in the western region of São Paulo city, on the campus of the University of São Paulo, at the left bank of the Pinheiros river (Figure 1). The campus area can be divided into two main topographic zones: a flat one in the north, corresponding to the flood plain of the Pinheiros river, now channeled, and a steepest one at the south with dense vegetal cover. Sedimentary formations occur in a great area of the campus: the São Paulo Formation and the Itaquaquecetuba Formation. The first one outcrops at the "prefeitura" and the Chemical Institute area. The second one occurs in the north part of the campus and close to the Olympic streak. These formations are related to fluvial deposits (meandering river and braided fluvial system deposits) and are constituted by conglomerates, sandstones and claystones. Quaternary alluvial deposits occur in the Olympic streak area. The bedrock is mainly constituted of granitic rocks, gneisses and migmatites and outcrops in the south and southeast areas of the campus where the topography is steeper (790 m) and locally in the northwest area of the campus (Av. Prof. Lineu Prestes, close to IPEN and the universitary Hospital). A more detailed description of the geological aspects of the São Paulo sedimentary basin and campus area can be found in Riccomini and Coimbra (1992), Iritani 


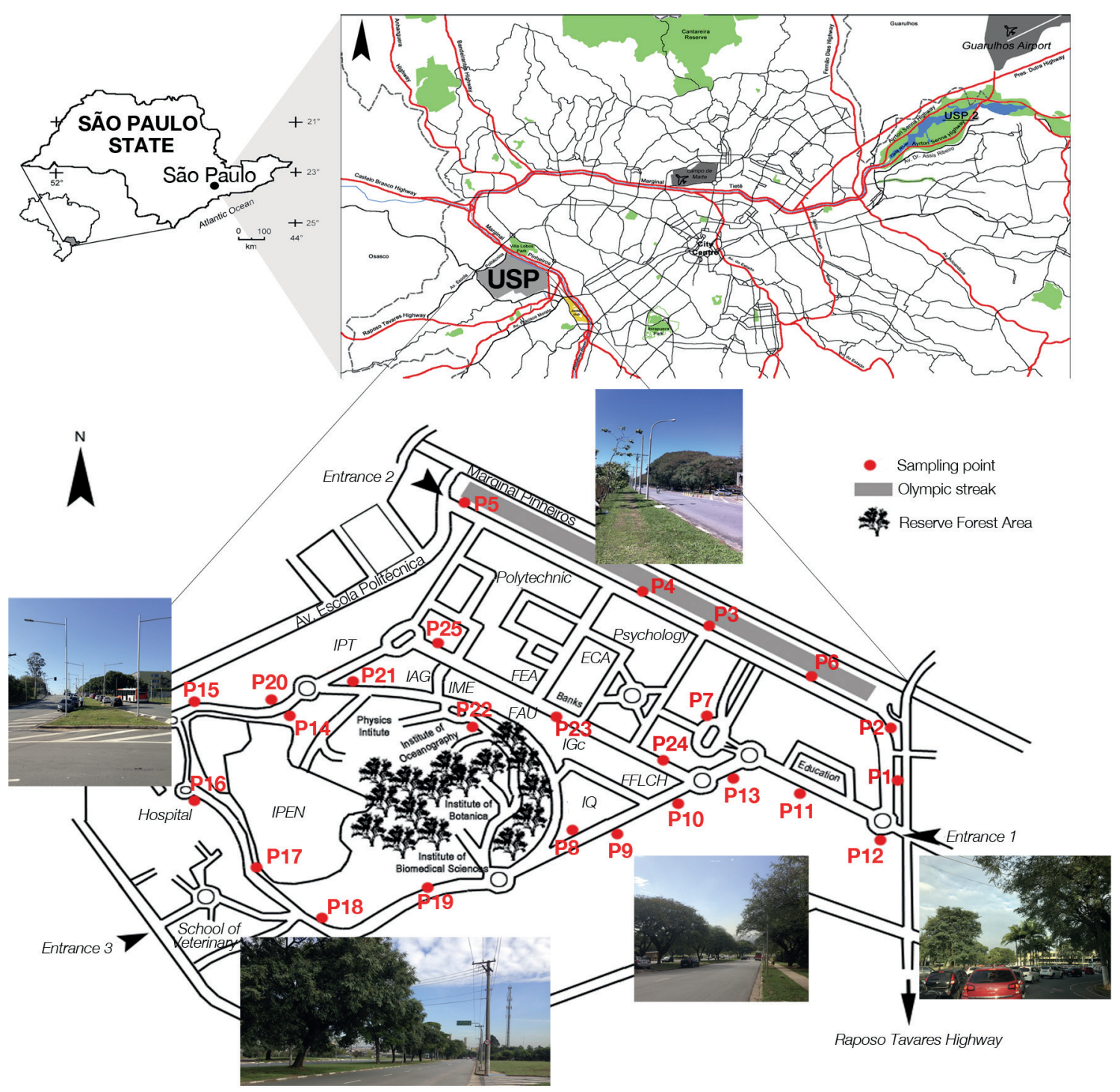

Figure 1 - Topsoil sampling sites located at the campus (green area) of the University of São Paulo, in the west zone of the São Paulo city.

(1993) and Porsani et al. (2004). Natural soils originate from this lithology but have been affected by anthropogenic activities related to building and pavement construction. The campus is also a green area $\left(4.3 \mathrm{~km}^{2}\right)$ used as a park for practice and sporting events during weekends or holidays. Green areas and gardens cover about $25 \%$ of the campus area and native vegetation is preserved in a reserve forest area of 10ha. Important avenues with intense traffic of light- and heavy-duty vehicles surround the campus. The area is also inside a commercial and residential zone of the city and some small manufacturing activities (metallurgy, cement and food manufacturing). Surrounding the campus, arterial streets (speed limit of $50 \mathrm{~km} / \mathrm{h}$ ) and "marginal Pinheiros" (a peripheral road with a higher speed limit of $90 \mathrm{~km} / \mathrm{h}$ ) with circulation of all vehicles types (cars, trucks, buses, motorcycles). On the campus, cars and buses flow all day. During rush hours, heavy circulation and stop and go-traffic increase at the three main entrances of the campus. 


\section{SAMPLING METHODS AND PREPARATION}

Topsoils $(0-10 \mathrm{~cm})$ were sampled in a $5 \mathrm{~m}^{2}$ area where 6 subsamples were mixed to obtain a bulk sample at each sampling point. The characteristics of each area such as proximity of parking areas, main streets, bus stops and green areas conditioned the sampling point locations (Figure 1). The distance between the sampling point and the road varied from 1 to $5 \mathrm{~m}$ and $80 \%$ of sampling points were close to a bus stop. In each sampling point, a total of $1 \mathrm{~kg}$ of sample was collected and stored in plastic bags until preparation and analysis. Sampling was performed from July to August 2012 (winter dry season) totalizing 25 samples.

Samples were air-dried at room temperature and sieved through a $2 \mathrm{~mm}$ mesh nylon sieve to remove stones, roots, leaves or any other greater materials. All samples were homogenized and divided by a successive quartering method to provide a representative sample. This fraction $(<2$ $\mathrm{mm}$ ) was divided into several aliquots for laboratory analyses. Samples were grinded to fine powder in an agate mortar for acid digestion and X-Ray Diffraction analyses. Element concentrations in the digest extracts were quantified by ICP-MS.

\section{ANALYTICAL METHODS}

Size fraction analyses consisted to the separation of sedimentology classes into $0.5 \phi$ intervals between 2.00 and $0.0062 \mathrm{~mm}$ and into intervals of $1 \phi$ for silt and clay classes.

Topsoil mineralogy was determined by X-Ray powder Diffraction analysis (XRD). Diffraction patterns were obtained using a Bruker D8 diffractometer coupled with a LYNXEYE detector operated at $40 \mathrm{kV}$, current of $40 \mathrm{~mA}$, a Cu source $(\mathrm{K} \alpha$ radiation), with a step mode of $0.02^{\circ}(2 \theta)$ ranging from $2^{\circ}$ to $65^{\circ}$ and counting time of $0.5 \mathrm{~s}$ per step.

Total Carbon was also quantified in soil samples (LECO, CHN 1000 model) according to the methodology established by Andrade et al. (2009).
Analyses of total elemental composition were carried out after hot acid digestion (Aqua Regia) of $0.5 \mathrm{~g}$ of samples and quantified by ICP-MS at ACME Analytical Laboratories, accredited by ISO/ IEC 17025. The Aqua Regia digestion provides partial results for most elements since it not attacks silicate minerals and it is generally used to estimate the mobility, behavior and element availability to plants. Major elements (as oxide forms) and 53 trace elements were quantified in soil samples but, for trace metals, arsenic (As), barium (Ba), cadmium $(\mathrm{Cd})$, cobalt $(\mathrm{Co})$, chromium $(\mathrm{Cr})$, copper $(\mathrm{Cu})$, molybdenum (Mo), nickel $(\mathrm{Ni})$, lead $(\mathrm{Pb})$, antimony (Sb), vanadium (V), zinc ( $\mathrm{Zn})$, mercury $(\mathrm{Hg})$, platinum $(\mathrm{Pt})$ and palladium $(\mathrm{Pd})$ will be discussed. The accuracy and precision of analyses were determined by using duplicate samples, blank samples and standard reference materials. The relative percent difference varied from $7 \%$ to $17 \%$ and standard recoveries ranged between $97 \%$ and $108 \%$.

Polycyclic Aromatic Hydrocarbons (PAHs) were extracted by an Accelerated Solvent Extraction System (ASE350, DIONEX Corporation) according to the following procedure: 2 static cycles of $10 \mathrm{~min}$ each using dichloromethane at a temperature of $100^{\circ} \mathrm{C}$ and a pressure of 100 bars. Each cell was filled with $4 \mathrm{~g}$ of soil mixed with diatomaceous earth that promotes a better homogenization of the sample, humidity retention, and interaction with solvent. After clean up through solid phase extraction cartridge (Bakerbond SPE silica gel) and elution with cyclohexane and cyclohexane-dichloromethane (4:1) mixture, the extracts were concentrated in a gentle $\mathrm{N}_{2}$ (analytical grade) flux and solvent changed with 1 $\mathrm{mL}$ of acetonitrile (HPLC grade) for quantification by High Performance Liquid Chromatography with Fluorescence detection (HPLC-FLU) (Fujita 2009). Thirteen PAHs (Acenaphthene-ACE, Fluorene-FLU, Phenanthrene-PHE, AnthraceneANT, Fluoranthene-FLT, Pyrene-PYR, Benzo(a) 
anthracene-BaA, Chrysene-CRY, Benzo(b) fluoranthene-BbF, Benzo(k)fluoranthene-BkF, Benzo(a)pyrene-BaP, Dibenzo(a,h)anthraceneDahA, Benzo(ghi)perylene-BghiP, Indeno(1,2,3cd)pyrene-IND) were quantified by HPLC-FLU (Varian 920LC model) with a $250 \mathrm{~mm}$ x $4.6 \mathrm{~mm}$ x $5 \mathrm{~mm}$ column (Supelcosil LC PAH), in the GRESCO Laboratory (Institute of ChemistryUNESP). The accuracy and precision of analyses were determined by using blank samples and standard reference materials (NIST SRM1649a Urban dust). Recoveries ranged between $70 \%$ and $107 \%$. Compounds with lower recoveries have not been considered.

\section{DATA ANALYSIS}

For PAHs, potential carcinogenic risk exposure for adult and children were calculated considering the toxic and mutagenic equivalent factors $\left(\mathrm{BaP}_{\mathrm{TEF}}\right.$ and $\mathrm{BaP}_{\mathrm{MEF}}$, respectively), that is the toxicity of PAHs relative to BaP. Exposition through inhalation, ingestion and dermal contact routes was also evaluated through the Incremental Lifetime Cancer Risk model (ILCR). Calculation details were obtained from the studies of Ha et al. (2016) and Peng et al. (2011). For $\mathrm{BaP}_{\mathrm{TEF}}$ and $\mathrm{BaP}_{\mathrm{MEF}}$ calculation, we considered PAHs with higher molecular weight i.e. BaA, CHRY, BbF, BkF, BaP, IND, DahA and BghiP, according to Jung et al. (2010).

Multivariate data analysis was performed using the Positive Matrix Factorization (PMF) model (version 5.0), an operational system from the United States Environmental Protection Agency (US-EPA). This model was developed to source apportionment analysis in environmental studies, which consider the error of instrumental measurements. It is a multivariate analysis technique used in the evaluation and modeling environmental data set such as in lake and river sediments (Bzdusek et al. 2006, Comero et al. 2014, Yu et al. 2015), soils (Vaccaro et al. 2007, Syed et al. 2017, Guan et al. 2018). The analysis was performed for elemental and PAHs concentrations. The number of factors was adjusted to obtain the best $\mathrm{Q}_{\text {theory }} \approx \mathrm{Q}_{\text {robust }}$ and physical validity of the model. Estimation of the goodness of the model fit was achieved by minimal values of $Q$ and a scaled residual between -2 and +2 , following the recommendations of Reff et al. (2007).

The spatial distribution study of metals and PAHs was performed by ArcGIS 10 mapping software.

\section{RESULTS AND DISCUSSION}

\section{SOIL CHARACTERISTICS}

Soil texture was predominantly medium to fine with a great variation of sand, silt and clay content and showing sandy loam, sandy clay loam and loam textures. The results of particle size analysis showed that average clay content was $221 \pm 61.8 \mathrm{~g}$ $\mathrm{kg}^{-1}$, average silt and sand contents were $267 \pm 61.9 \mathrm{~g}$ $\mathrm{kg}^{-1}$ and $511 \pm 95.5 \mathrm{~g} \mathrm{~kg}^{-1}$, respectively. P22 showed the lowest silt $\left(95.7 \mathrm{~g} \mathrm{~kg}^{-1}\right)$ and clay $\left(81.8 \mathrm{~g} \mathrm{~kg}^{-1}\right)$ and highest sand $\left(823 \mathrm{~g} \mathrm{~kg}^{-1}\right)$ content values whereas P23 showed the highest silt $\left(374 \mathrm{~g} \mathrm{~kg}^{-1}\right)$ and clay (328 $\left.\mathrm{g} \mathrm{kg}^{-1}\right)$ and lowest sand $\left(298 \mathrm{~g} \mathrm{~kg}^{-1}\right)$ content. Quartz pebbles were found in topsoils at P3, P4 and P5 sites, which are close to the Olympic streak and may characterize a layer related to the landfilling of old sand pits. We also found gravel mixed to topsoil at P18 site, and plastic fragments mixed to concrete construction fragments at $\mathrm{P} 22$ site.

X-Ray Diffraction results showed that primary minerals such as quartz, mica and feldspars constituted topsoil mineralogy associated with kaolinite and gibbsite. In some samples, iron oxides (hematite/goethite), other clay minerals, amphibole and rutile were also identified.

MAJOR AND TRACE ELEMENTS, TOTAL CARBON

Descriptive statistics of major elements, trace elements and soil Total carbon (C) concentrations are presented in Table I. As expected for tropical 
TABLE I

Major and trace elements and $\mathrm{C}_{\text {tot }}$ content in topsoils (min. - minimum; max.- maximum; std. - standard deviation).

\begin{tabular}{|c|c|c|c|c|c|c|c|c|c|}
\hline \multicolumn{5}{|c|}{ MAJOR ELEMENTS } & \multicolumn{5}{|c|}{ TRACE ELEMENTS } \\
\hline & mean & std. & $\min$. & $\max$. & & mean & std. & $\min$. & $\max$. \\
\hline & \multicolumn{4}{|c|}{$\left(\mathrm{g} \mathrm{kg}^{-1}\right)$} & & \multicolumn{4}{|c|}{$\left(\mathrm{mg} \mathrm{kg}^{-1}\right)$} \\
\hline Al & 80.5 & 12.8 & 43.2 & 103 & As & 5.14 & 1.64 & 2.10 & 8.70 \\
\hline $\mathbf{S i}$ & 305 & 21.0 & 274 & 368 & $\mathbf{B a}$ & 48.5 & 14.7 & 30.8 & 75.5 \\
\hline $\mathrm{Fe}$ & 33.1 & 6.54 & 18.0 & 49.4 & Cd & 0.59 & 0.60 & 0.18 & 2.96 \\
\hline $\mathbf{K}$ & 6.95 & 2.30 & 2.91 & 11.4 & Co & 3.73 & 2.63 & 1.60 & 14.6 \\
\hline $\mathrm{Ca}$ & 2.42 & 0.97 & 1.14 & 4.93 & $\mathrm{Cr}$ & 42.1 & 23.8 & 24.6 & 153 \\
\hline Mg & 1.27 & 0.63 & 0.66 & 3.79 & $\mathbf{C u}$ & 19.5 & 5.48 & 11.8 & 31.3 \\
\hline $\mathbf{N a}$ & 1.36 & 0.64 & 0.67 & 3.19 & Mo & 0.91 & 0.26 & 0.45 & 1.59 \\
\hline $\mathbf{P}$ & 0.45 & 0.09 & 0.26 & 0.61 & $\mathbf{N i}$ & 11.2 & 15.3 & 4.50 & 66.6 \\
\hline Mn & 0.25 & 0.09 & 0.16 & 0.54 & $\mathbf{P b}$ & 40.8 & 14.1 & 17.4 & 75.9 \\
\hline \multirow[t]{2}{*}{$\mathbf{T i}$} & 5.09 & 0.86 & 3.26 & 6.83 & $\mathbf{S b}$ & 0.32 & 0.11 & 0.13 & 0.56 \\
\hline & & & & & V & 63.4 & 15.7 & 26.0 & 91.0 \\
\hline \multirow[t]{5}{*}{$\mathrm{C}_{\text {tot }}$} & 25.1 & 6.30 & 15.3 & 39.8 & $\mathrm{Zn}$ & 94.6 & 50.8 & 38.5 & 275 \\
\hline & & & & & & \multicolumn{4}{|c|}{$\left(\mu \mathrm{g} \mathrm{kg}^{-1}\right)$} \\
\hline & & & & & $\mathbf{H g}$ & 79.0 & 40.0 & 22.0 & 197 \\
\hline & & & & & $\mathbf{P t}$ & 2.80 & 1.87 & $1.00 *$ & 7.00 \\
\hline & & & & & Pd & 8.04 & 7.55 & $5.00 *$ & 40.0 \\
\hline
\end{tabular}

*value is corresponding to half the limit detection value (2.00 and $10.0 \mu \mathrm{g} \cdot \mathrm{kg}^{-1}$ for Pt and $\mathrm{Pd}$, respectively).

soils, Si, Al and Fe predominated in topsoil composition. Si varied between $273.8 \mathrm{~g} \mathrm{~kg}^{-1}$ and $367.9 \mathrm{~g} \mathrm{~kg}^{-1}$, Soil total carbon content was low $(<25$ $\mathrm{g} \mathrm{kg}^{-1}$ on average).

The order of trace metal concentration measured in topsoils was: $\mathrm{Zn}>\mathrm{V}>\mathrm{Ba}>\mathrm{Cr}>\mathrm{P}$ $\mathrm{b}>\mathrm{Cu}>\mathrm{Ni}>\mathrm{As}>\mathrm{Co}>\mathrm{Mo}>\mathrm{Cd}>\mathrm{Sb}$. Trace metal concentrations showed a great variation between sampling point for most of the metals (Figure 2). However, these concentrations did not exceed the quality reference values established by the São Paulo State Environmental Agency (CETESB 2014), except for $\mathrm{As}, \mathrm{Pb}, \mathrm{Zn}, \mathrm{Cr}$ and $\mathrm{Hg}$ in most sampling points and for $\mathrm{Co}, \mathrm{Cd}, \mathrm{Ni}, \mathrm{Sb}$ only in few points. Some metal concentrations $(\mathrm{Cd}$ and Ni) exceed the Prevention Values established by CETESB.

Trace metal concentrations measured in this study were lower than trace metal concentrations in natural and urban Brazilian and World soils (Table II), except for $\mathrm{Cu}, \mathrm{Pb}, \mathrm{Zn}, \mathrm{As}$ and V. Also, $\mathrm{Zn}$ concentrations in this study were higher than those reported to urban green parks topsoils from São Paulo city. Comparing topsoil trace metal concentrations at the campus with those obtained from urban forest soils in the São Paulo city (PEFI) and in natural soils of the Serra do Mar State Park (Cunha) (Bourotte 2009), Cu, Ni, Zn and Pb showed higher concentrations. For reference values of $\mathrm{Cd}, \mathrm{Co}, \mathrm{Cr}, \mathrm{Cu}, \mathrm{Ni}, \mathrm{Pb}$ and $\mathrm{Zn}$ concentration in background soils from the São Paulo State, we chose data from Fadigas et al. (2006), who compiled trace elements concentrations in several typical soils of the São Paulo State. Average concentrations for $\mathrm{Zn}$ and $\mathrm{Pb}$ in our study soils are 3.2 and 2 times higher, respectively, than these background values. The concentrations in our study soils were similar for $\mathrm{Cr}$ and lower for $\mathrm{Ni}, \mathrm{Co}$ and $\mathrm{Cd}$. Results also 


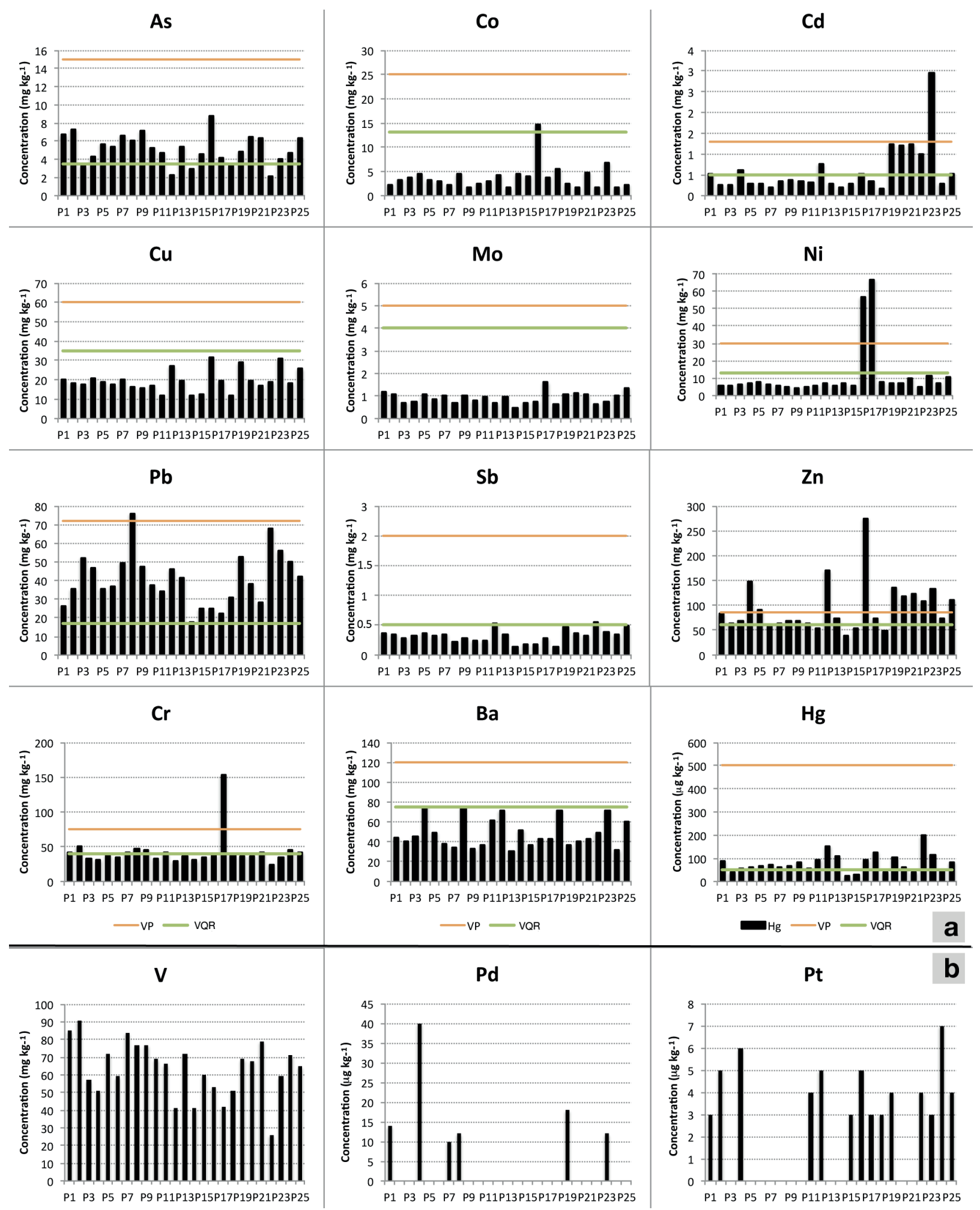

Figure 2 - a) Variation of trace metals concentration $\left(\mathrm{mg} \mathrm{kg}^{-1}\right)$ in superficial soils and comparison with the Quality Reference (VQR) and Prevention values (VP) established by CETESB (2014). b) Variation of vanadium concentration ( $\left.\mathrm{mg} \mathrm{kg}^{-1}\right)$, platinum and palladium concentration $\left(\mu \mathrm{g} \mathrm{kg}^{-1}\right.$ ) in topsoils (No Quality Reference Values or Prevention Values have been established by CETESB for these trace metals). 
showed an enrichment of $\mathrm{Cu}$ and $\mathrm{Zn}$ in topsoils with respect to rock basement (Table II).

In urban areas, soils generally exhibit trace metal content higher than background levels (Wong and Thornton 2006, Manta et al. 2002, Luo et al. 2012, Werkentin et al. 2014, Alekseenko and Alekseenko 2014). Thus, in order to better identify possible metal correlations and sources associated, a statistical analysis has been performed. Spearman correlation was chosen to account for the nonparametric data distributions. The results showed a strong association $(>0.5$ and significant at $\mathrm{p}<0.050)$ between $\mathrm{As}, \mathrm{Mo}, \mathrm{V}$ and $\mathrm{Cr}$; $\mathrm{Co}, \mathrm{Ni}$ and $\mathrm{Ba} ; \mathrm{Cd}, \mathrm{Cu}$, $\mathrm{Sb}, \mathrm{Zn}$, and $\mathrm{Hg}$; $\mathrm{Cu}, \mathrm{Ni}$, Sb, Hg, Pt, Pd and $\mathrm{Zn}$; Pb, $\mathrm{Sb}$ and $\mathrm{Pt}$.

Automobile catalyzers are the main source of $\mathrm{Pd}$ and Pt in roadside soils (Whiteley and Murray 2003, Wiseman and Zereini 2009, Reith et al. 2014). $\mathrm{Pt}$ and $\mathrm{Pd}$ concentrations ranged between 1.00 to $7.00 \mu \mathrm{g} . \mathrm{kg}^{-1}$ and 5.00 to $40.00 \mu \mathrm{g} . \mathrm{kg}^{-1}$, respectively. As pointed out by Morcelli et al. (2005) who studied these elements in some road-soils of the São Paulo city, traffic conditions and distance from the road influenced their concentrations in topsoils. In Brazil, automobile catalyzers are in use since 1996 and Morcelli et al. (2005) also pointed out that they contain lower Pt concentrations than European catalytic converters. The strong correlation between Pt and Pd indicated this common vehicle source. Average $\mathrm{Pt} / \mathrm{Pd}$ ratios obtained in this study were 0.46 that is similar to ratios obtained in other studies (Morcelli et al. 2005, Ribeiro et al. 2012).

Other metals may also be associated with vehicular sources since $\mathrm{Cu}, \mathrm{Zn}$ and $\mathrm{Pb}$ are common constituents of vehicle components. Tire wears, break pads, lubricant oils are also considered as contributors in urban pollution (Davis et al. 2001, McKenzie et al. 2009, Mielke et al. 2001, Thorpe and Harrison 2008, Wiseman and Zereini 2009, Adachi and Tainosho 2004). Element ratios may indicate the contribution of brake dusts and tire wear dusts (McKenzie et al. 2009). In brakes, $\mathrm{Cu}$ is enriched over $\mathrm{Zn}$ and $\mathrm{Cu} / \mathrm{Zn}$ ratio is $>1$ but $\mathrm{Pb}, \mathrm{Cd}, \mathrm{Cr}, \mathrm{Ni} / \mathrm{Zn}$ $<1$. In this study, mean values for $\mathrm{Pb} / \mathrm{Zn}$ and $\mathrm{Cu} / \mathrm{Zn}$ were 0.50 and 0.23 respectively. For tire wears, $\mathrm{Zn}$ is a tracer (Thorpe and Harrison 2008) and $\mathrm{Zn} / \mathrm{Cu}>1$. In this study, the mean value for this ratio was 2.18 and 4.68 for $\mathrm{Zn} / \mathrm{Cu}$, which may indicate automobile contribution as a source for these metals. Antimony was also statistically associated with these metals. Varrica et al. (2013) showed that antimony might also be significantly released in urban environment through brake abrasion processes since stibinite $\left(\mathrm{Sb}_{2} \mathrm{~S}_{3}\right)$ is used in brake linings. Adachi and Tainosho (2004) and Quiroz et al. (2013) also associated this element with brake dusts. $\mathrm{Pb}$ is generally attributed to vehicular emissions but since 1989, lead has been banned from gasoline in Brazil and totally eliminated since 1992. The addition of ethanol to gasoline substituted $\mathrm{Pb}$ for its anti-knock property. However, although lead concentrations decreased in the urban atmosphere, lead contamination remain as a problem in the urban environment, mostly due to other sources and its accumulation in surface soils and slow release to environment. In São Paulo city, according to Gioia et al. (2010) the isotopic signature of lead showed that $71.6 \%$ of $\mathrm{Pb}$ is derived from gasoline, even though vehicular emissions have low $\mathrm{Pb}$ concentrations. Although $\mathrm{Pb}, \mathrm{Cu}$ and $\mathrm{Zn}$ are usually associated with automobile sources (Zn-tire wears, $\mathrm{Cu}$-brake and vehicle components), other trace metals such as $\mathrm{Ni}, \mathrm{As}, \mathrm{Cd}$ and $\mathrm{Cr}$ also accumulated in urban soils. These metals are associated to vehicular emissions, industrial sources and other sources as wood preservatives and pesticides for As. Sternbeck et al. (2002) also associated $\mathrm{Cu}, \mathrm{Zn}, \mathrm{Sb}, \mathrm{Ba}$ and $\mathrm{Pb}$ to vehicle-derived metals and not to combustion processes.

PAHs

The sum of 13 PAHs in topsoil samples had an average of $0.33 \mathrm{mg} \mathrm{kg}^{-1}\left[0.07-1.38 \mathrm{mg} \mathrm{kg}^{-1}\right]$ (Table III) and fluorene, indeno(1,2,3-cd)pyrene, anthracene, 
CHRISTINE L.M. BOUROTTE et al.

TRACE METALS AND PAHS IN SÃO PAULO TOPSOILS

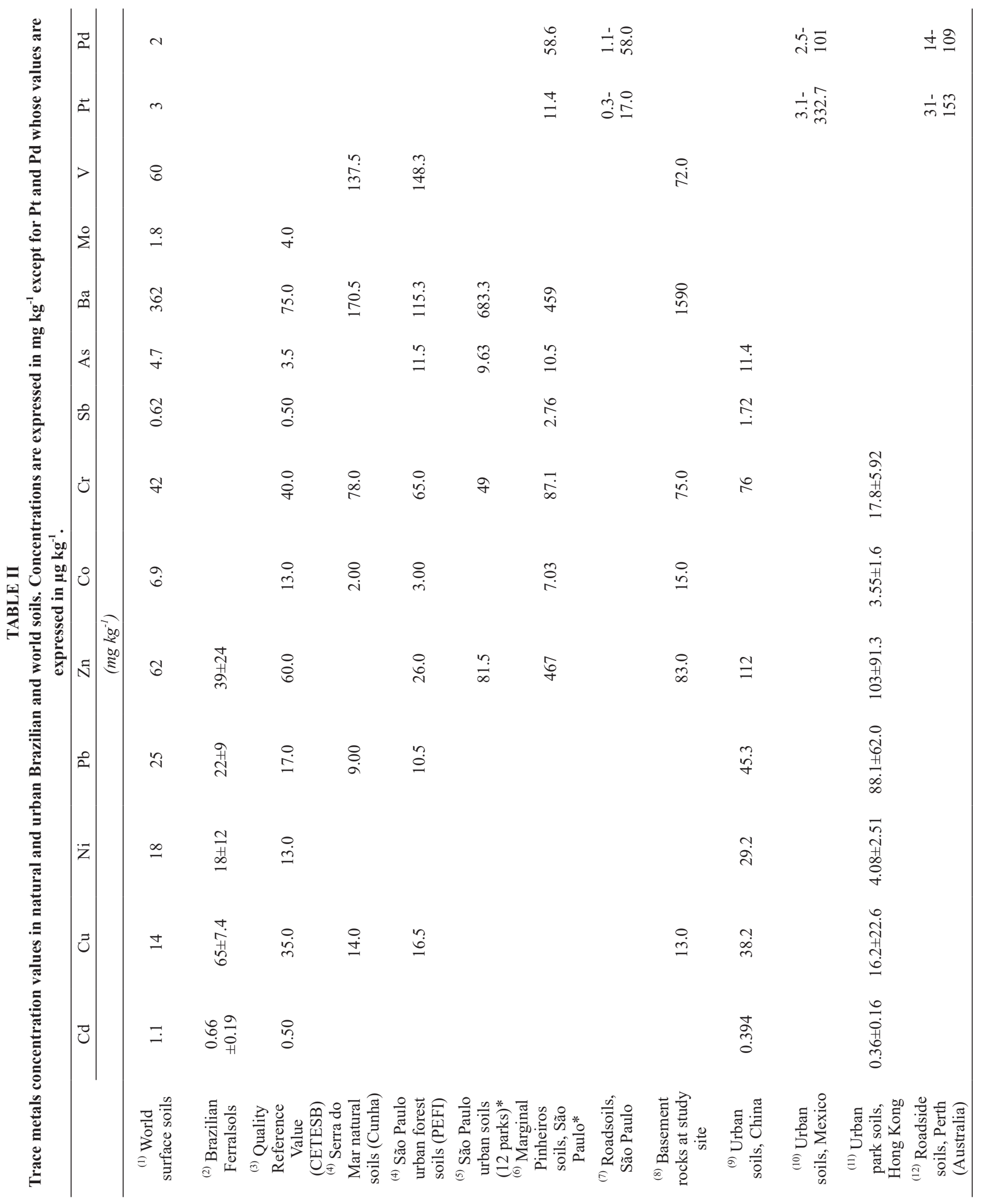




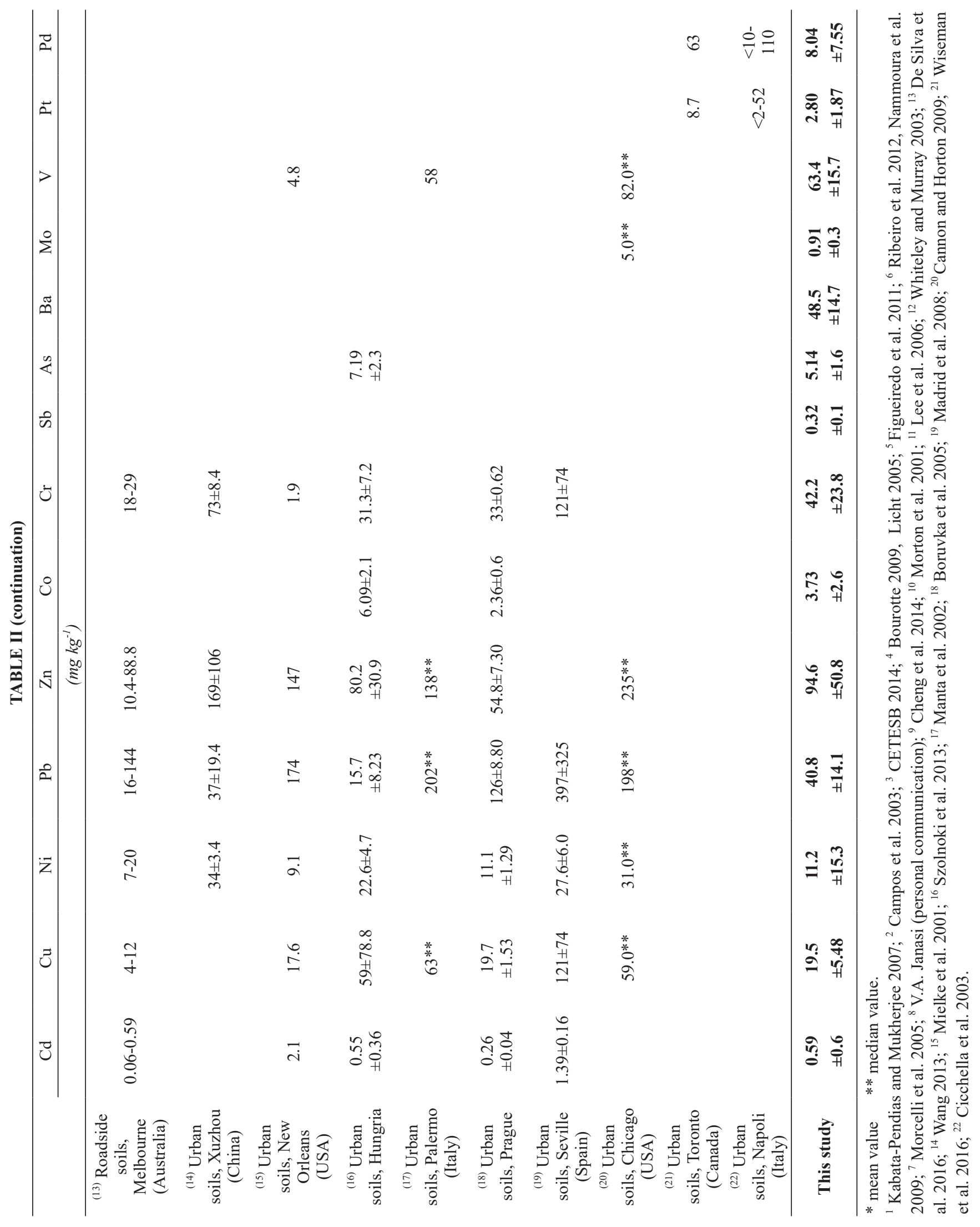


TABLE III

Statistics for PAHs concentration in topsoil samples from USP campus in the São Paulo city (min. - minimum; max.maximum; std. - standard deviation).

\begin{tabular}{|c|c|c|c|c|c|c|}
\hline & \multicolumn{6}{|c|}{ PAHs } \\
\hline & $n$ & mean & std. & $\min$. & $\max$ & $\begin{array}{c}\text { Prevention } \\
\text { Value* }\end{array}$ \\
\hline & & & $\left(\mathrm{mg} \mathrm{kg}^{-1}\right)$ & & & $\left(m g k g^{-1}\right)$ \\
\hline Acenaphthene (ACE) & 6 & 0.017 & 0.015 & 0.003 & 0.041 & - \\
\hline Fluorene (FLU) & 10 & 0.102 & 0.076 & 0.008 & 0.208 & - \\
\hline Phenanthrene (PHE) & 14 & 0.001 & 0.001 & 0.000 & 0.003 & 3.6 \\
\hline Anthracene (ANT) & 15 & 0.060 & 0.058 & 0.001 & 0.164 & 0.3 \\
\hline Fluoranthene (FLT) & 8 & 0.008 & 0.005 & 0.002 & 0.015 & - \\
\hline Pyrene (PYR) & 11 & 0.043 & 0.063 & 0.004 & 0.220 & - \\
\hline Benzo(a)anthracene (BaA) & 15 & 0.020 & 0.016 & 0.004 & 0.046 & 0.2 \\
\hline Chrysene (CHRY) & 14 & 0.038 & 0.020 & 0.003 & 0.068 & 1.6 \\
\hline Benzo(b)fluoranthene (BbF) & 15 & 0.008 & 0.006 & 0.001 & 0.023 & 0.7 \\
\hline Benzo(k)fluoranthene (BkF) & 12 & 0.036 & 0.063 & 0.007 & 0.234 & 0.8 \\
\hline Benzo(a)pyrene (BaP) & 1 & 0.275 & - & 0.000 & 0.275 & 0.1 \\
\hline Dibenz(a,h)anthracene (DBahA) & 8 & 0.038 & 0.027 & 0.012 & 0.083 & 0.2 \\
\hline Benzo(ghi)perylene (BghiP) & 11 & 0.041 & 0.033 & 0.004 & 0.109 & 0.5 \\
\hline Indeno(1,2,3-cd)pyrene (IND) & 9 & 0.067 & 0.044 & 0.013 & 0.160 & 0.4 \\
\hline$\sum$ PAHs & 17 & 0.329 & 0.325 & 0.072 & 1.379 & \\
\hline$\sum$ Low Molecular Weight PAHs & 17 & 0.120 & 0.096 & 0.001 & 0.322 & \\
\hline$\sum$ High Molecular Weight PAHs & 17 & 0.209 & 0.259 & 0.0000 & 1.1183 & \\
\hline$\sum$ Carcinogenic & 17 & 0.157 & 0.181 & 0.0000 & 0.7767 & \\
\hline$\sum$ 2-3 rings & 17 & 1.120 & 0.096 & 0.001 & 0.322 & \\
\hline$\sum 4$ rings & 17 & 0.080 & 0.071 & 0.000 & 0.318 & \\
\hline$\sum 5$ rings & 17 & 0.067 & 0.139 & 0.000 & 0.595 & \\
\hline$\sum 6$ rings & 17 & 0.062 & 0.072 & 0.000 & 0.241 & \\
\hline
\end{tabular}

* São Paulo State Environmental Agency - CETESB 2014.

pyrene and benzo(ghi)perylene were the most abundant compounds, accounting for $31 \%, 20.2 \%$, $18.2 \%, 12.9 \%, 12.5 \%$ of total PAHs, respectively (Figure 3a). On average, low molecular weight PAHs account for $40 \%$ and high molecular weight PAHs for $60 \%$ of total PAHs, indicating that high temperature combustion processes are the dominant sources of PAHs (Figure 3b). Benzo(a)pyrene, the most carcinogenic PAHs, has been detected only in one sampling site, exceeding the prevention value recommended by CETESB (2014). The frequency of individual PAHs have shown that anthracene, benzo(a)anthracene and benzo(b)fluoranthene are the dominant compounds in almost all samples. The sum of carcinogenic PAHs (BaA, CHRY, BbF, $\mathrm{BkF}, \mathrm{BaP}, \mathrm{DBahA}$, IND) accounted for $44.0 \pm 15.5 \%$ of the total PAHs, on average (Figure 3c). Higher proportions of 2-3 rings PAHs contributed to the total PAHs (39.8 $\pm 24.1 \%$ ) followed by 4-rings PAHs $(27.1 \pm 13.8 \%)$, 5-rings PAHs $(17.1 \pm 17.7 \%)$ and 6-rings PAHs (16.0 $\pm 12.8 \%)$ as shown in Figure 3d.

The comparison of PAHs concentrations in urban topsoils worldwide (Table IV), has shown that values found in this study are lower than in 

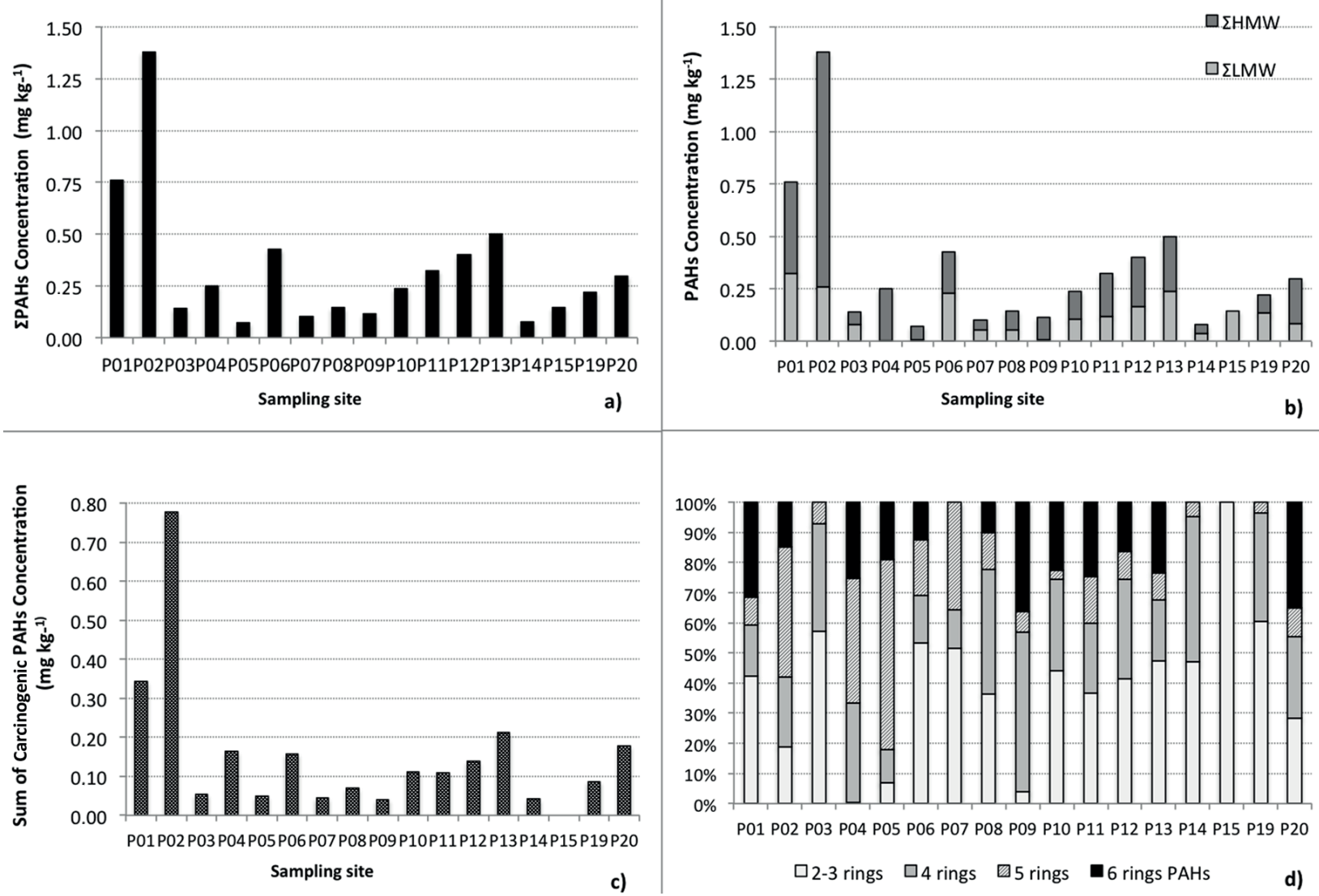

Figure 3 - Variation of (a) $\sum$ PAHs concentrations $\left(\mathrm{mg} \mathrm{kg}^{-1}\right)$, (b) sum of low (LMW) and heavy molecular weight (HMW) PAHs concentrations ( $\left.\mathrm{mg} \mathrm{kg}^{-1}\right)$, (c) $\sum$ carcinogenic PAHs (BaA, CHRY, BbF, BkF, BaP, DBahA, IND) concentrations ( $\left.\mathrm{mg} \mathrm{kg}^{-1}\right)$, and (d) aromatic ring numbers percentage distribution between sampling sites.

Chinese cities (Beijing - 11.7 millions inhabitants, Dalian - 3.6 millions inhabitants, Shangai - 23 millions inhabitants, Nanjing - 3.6 millions inhabitants, Hong Kong - 7.2 millions inhabitants), Bangkok (5 millions inhabitants) and Dehli (11 millions inhabitants). Concentrations are also lower than cities of the North Hemisphere (Europe and United States). Some authors (Wilcke 2000,Wilcke et al. 1999, 2007, Zhang et al. 2006) have already pointed out this difference between temperate and tropical soils and it is generally attributed to microbial degradation, photo-oxidation and higher volatilization of compounds in tropical climate, which shorten their accumulation time. In addition, emission history in South Hemisphere is shorter and biomass burning and natural background from biological sources have also been pointed out to explain this difference. Total PAHs concentrations are similar to those obtained in urban surface soils of Huizhou and Zhanjiang (China), Ulsan (South Korea) and Kumasi (Ghana). The comparison with other studies in Brazil is more difficult since they are scarce.

However, the $\sum$ PAHs concentrations are 2 to 5 times higher than natural soils of Amazonian and Mata Atlântica Forests (Cunha) or other regions (Wilcke et al. 1999, 2003, Krauss et al. 2005, Bourotte et al. 2009). Considering the urban forest park (PEFI) located within the urban area of São Paulo city (in the south part of the city), $\sum$ PAHs concentrations are 2.5 times higher than those obtained in this study. 
TABLE IV

Comparison of average PAHs concentrations (in $\mathrm{mg} \mathrm{kg}^{-1}$ ) in this study and in world topsoils.

\begin{tabular}{|c|c|c|c|c|}
\hline Location & Concentration & $\begin{array}{l}\text { Number } \\
\text { of PAHs }\end{array}$ & Area & Reference \\
\hline São Paulo, Brazil & $0.33 \pm 0.32[0.07-1.38]$ & 13 & $\begin{array}{l}\text { campus of the university } \\
\text { (urban green area) }\end{array}$ & This study \\
\hline \multirow{2}{*}{$\begin{array}{l}\text { São Paulo, Brazil } \\
\text { Cunha, Brazil }\end{array}$} & 0.818 & 16 & urban forest (PEFI) & \multirow{2}{*}{ Bourotte et al. 2009} \\
\hline & 0.180 & 16 & natural forest soils & \\
\hline Uberlândia, Brazil & {$[0.007-0.390]$} & 20 & urban & Wilcke et al. 1999 \\
\hline \multirow[t]{3}{*}{ Manaus, Brazil } & $0.016-0.038$ & 21 & Amazonian forest soils & \multirow[t]{3}{*}{ Krauss et al. 2005} \\
\hline & $0.145[0.015-0.397]$ & 20 & Terra Firme, Amazon Basin & \\
\hline & $0.068[0.029-0.142]$ & 20 & Pantanal & \\
\hline \multirow[t]{3}{*}{ Brazil } & $0.017[0.0048-0.035]$ & 20 & Cerrado central & \multirow[t]{3}{*}{ Wilcke et al. 2003} \\
\hline & $0.115[0.062-0.143]$ & 20 & Mata Atlântica & \\
\hline & $0.023[0.0071-0.064]$ & 20 & Caatinga & \\
\hline Beijing, China & $0.865 \pm 0.799$ & & residential & Peng et al. 2013 \\
\hline \multirow[t]{4}{*}{ Beijing, China } & $1.285 \pm 1.848$ & 16 & park & \multirow[t]{4}{*}{ Peng et al. 2011} \\
\hline & $1.026 \pm 0.726$ & & roadside (heavy traffic) & \\
\hline & $0.538 \pm 0.340$ & & roadside (light traffic) & \\
\hline & $0.811 \pm 0.748$ & & residential & \\
\hline Beijing, China & $1.803 \pm 1.824$ & 16 & urban soils & Liu et al. 2010 \\
\hline \multirow[t]{2}{*}{ Dalian, China } & $4.391 \pm 4.370$ & 25 & garden & \multirow[t]{2}{*}{ Wang et al. 2009} \\
\hline & $3.237 \pm 2.735$ & & business/residential & \\
\hline Shangai, China & $1.97[0.083-7.220]$ & 16 & urban soils & Wang 2013 \\
\hline Nanjing, China & $3.330[0.059-18]$ & 16 & urban soils & Wang et al. 2015 \\
\hline Huizhou, China & {$[0.0354-0.5345]$} & 16 & urban soils & Ma and Zhou 2011 \\
\hline Zhanjiang, China & {$[0.0095-6.618]$} & 16 & urban soils & \\
\hline Bangkok, Thailand & 0.1292 & 20 & urban soils & Wilcke et al. 1999 \\
\hline \multirow[t]{2}{*}{ Shangai, China } & 6.280 & 16 & roadside soils & \multirow[t]{2}{*}{ Jiang et al. 2009} \\
\hline & 2.130 & 16 & park & \\
\hline Hong Kong, China & $0.169[0.007-0.410]$ & 16 & urban soils & Zhang et al. 2006 \\
\hline \multirow[t]{2}{*}{ Ulsan, South Korea } & $0.390[0.065-1.200]$ & 16 & urban soils & \multirow{2}{*}{ Kwon and Choi 2014} \\
\hline & $0.220[0.092-0.450]$ & 16 & rural soils & \\
\hline Kumasi, Ghana & $0.4425 \pm 0.5272$ & 22 & urban soils & Bortey-Sam et al. 2014 \\
\hline Argentina & $0.0075[0.0017-0.031]$ & 16 & soils transect & Wilcke et al. 2014 \\
\hline Dehli, India & $4.694 \pm 3.028[1.062-9.652]$ & 16 & traffic site & Agarwal 2009 \\
\hline Lisbon, Portugal & 1.544 & 16 & urban & \multirow{2}{*}{ Cachada et al. 2012} \\
\hline Viseu, Portugal & 0.169 & 16 & urban & \\
\hline Bayreuth, Germany & 37.3 & 20 & roadside soils & Wilcke et al. 2002 \\
\hline Bergen, Norway & 6.780 & 16 & urban soils & Haugland et al. 2008 \\
\hline New Orleans, USA & $3.731[0.647-40.692]$ & 16 & urban & Mielke et al. 2001 \\
\hline New Orleans, USA & 5.100 & 17 & urban soils & \multirow{2}{*}{ Wang et al. 2008} \\
\hline Detroit, USA & 7.843 & 17 & urban soils & \\
\hline London, UK & 18 & 16 & urban soils & Vane et al. 2014 \\
\hline Taragona, Spain & 0.736 & 16 & urban/residential zone & Nadal et al. 2004 \\
\hline Rouen, France & $2.780 \pm 0.879$ & 14 & urban site & Motelay-Massei et al. 2004 \\
\hline Galsgow, UK & {$[1.487-51.822]$} & 15 & urban & \multirow{2}{*}{ Morillo et al. 2007} \\
\hline Torino, Italy & {$[0.148-3.410]$} & 15 & urban & \\
\hline
\end{tabular}

PAHs occurrence in soil depends on two major sources: a natural one related to diagenesis of organic matter, biological activities and fires, and another one, associated to high combustion processes and products such as incomplete combustion of fossil fuels, vehicular engine combustion, smelting, waste incinerators. This pyrogenic source usually presents a pattern composed with high molecular weight PAHs. Petrogenic sources of PAHs include unburned petroleum and related products such 
as gasoline, kerosene, diesel and lubricating oil. Since the urban area is a complex environment, the identification of PAHs sources is difficult and may be provided by statistical analysis, PAHs profiles and/or PAHs ratios.

There were positive correlations among the concentrations of ANT, BaA, CHRY, BbF and BkF; BaA, CHRY, BkF and BghiP; and $\mathrm{CHRY}$ and BghiP which may indicate common sources for these compounds. PHE and IND were negatively correlated. According to Tobiszewski and Namiesnik (2012), PAHs diagnostic ratios are tools used to identify emissions sources. However, diagnostic ratios results must been considered with caution since they may change during transport and environmental degradation processes. According to Mostert et al. (2010), low temperature processes usually produce low molecular weight PAHs whereas high temperature processes such as combustion fuel in engine, usually produce high weight molecular compounds. Thus, in order to identify PAH sources, the LMW/HMW ratios were calculated considering the sum of low PAHs (ACE, FLU, PHE, ANT) and high molecular weight PAHs (FLT, PYR, BaA, CHRY, BbF, BkF, $\mathrm{BaP}, \mathrm{IND}, \mathrm{DBah}$, BghiP). The ratios showed that among the sampling sites, 11 sites were affected by pyrogenic sources and 4 sites (P03, P06, P07 and P19) were affected by petrogenic sources. Other PAHs diagnostic ratios are usually used to assess specific sources. Commonly used PAHs ratios are FLU/(FLU+PYR), ANT/(ANT+PHE), FLT/(FLT+PYR), BaA/(BaA+CHRY), IND/ (IND+BghiP) only mentioning some of them. Tobiszewski and Namiesnik (2012) also emphasized that $\mathrm{ANT} /(\mathrm{ANT}+\mathrm{PHE})$ and $\mathrm{BaA} /(\mathrm{BaA}+\mathrm{CHRY})$ ratios are more sensitive to photodegradation and environmental alterations than FLT/(FLT+PYR) and $\mathrm{IND} /(\mathrm{IND}+\mathrm{BghiP})$ ratios. In this study, the $\mathrm{BaA} /(\mathrm{BaA}+\mathrm{CHRY})$ ratio $(=0.36 \pm 0.2)$ indicated vehicular emissions/combustion sources which is similar with the values obtained by Bourotte et al. (2009) in urban forest soils and fine and coarse atmospheric particulate matter (Bourotte et al. 2005), and IND/(IND + BghiP) ratio (= $0.48 \pm 0.4)$ also indicated vehicular combustion.

The PAHs ratios indicated predominant combustion source in campus topsoils, which is in concordance with the LMW/HMW ratio results, and with other results for urban soils in São Paulo city (Bourotte et al. 2009). Since PAHs are primarily emitted into the atmosphere and accumulated in surface soil after transport by dry and wet atmospheric deposition (He et al. 2009), it should be interesting taking in account the PAHs concentrations in fine and coarse atmospheric particulate matter collected in the same area by Bourotte et al. (2005). PAHs ratios are similar to those obtained in atmospheric particulate matter and should confirm an atmospheric contribution, although the contamination of topsoils should also result from diffuse and punctual sources of contamination. Most of the samples were collected in the proximity of the street and/or near bus stops inside the campus area, thus mobile sources should directly contribute to the topsoil PAHs input. Lower molecular weight PAHs are more volatile and have a shorter half-life than the heavier compounds. Peng et al. (2012) emphasized that heavy PAHs deposited closer to the source since they are adsorbed on particulate matter and settled according to their size, the larger ones depositing more rapidly than the finer ones, that remain for a longer time in suspension in the atmosphere and may be deposited distant from their source. The main tracers for vehicular emissions are BbF, BghiP and IND, and according to Masclet et al. (1987), diesel exhausts are enriched in FLT, CHRY and PYR, whereas Kulkarni and Venkataraman (2000) also associated FLT, PYR, BbF and BkF to diesel emissions. Abrantes et al. (2009) studied Brazilian light duty diesel vehicle exhausts and characterized both gaseous and particulate phases compositions. The results showed that high molecular weight 
PAHs were predominantly adsorbed to soot particles as $100 \%$ for $\mathrm{BaA}, \mathrm{BaP}$, BghiP, $\mathrm{BkF}$, 98.6\% for CHRY, $97.5 \%$ for $\mathrm{BbF}$ and $96.5 \%$ for DBahA. Vehicles circulating in São Paulo city are also significantly fuelled by ethanol and gasohol as an alternative to fossil fuel, and more recently, by biofuel. According to Brito et al. (2013) ethanol was introduced in 1980s but its use has increased since the 2000s. Flexible fuel vehicles that can use either gasohol (a mixture of $20 \%$ anhydrous ethanol with gasoline) or pure ethanol included the fleet since 2003. Heavy-duty vehicles compose an older fleet but they are fuelled with a minimum of 5\% of biodiesel content since 2010. Tunnel measurements in São Paulo city showed that 3- and 4-rings particle phase PAHs accounted for 24 to $77 \%$ of vehicular emissions. PHE, BaA, BbF and DBahA were the most abundant compounds and were associated with light-duty vehicles emissions (Brito et al. 2013). On the other hand, Vasconcellos et al. (2003), in order to characterize particulate matter organic composition in São Paulo tunnels, have associated PYR, CHRY, BaA to gasohol and diesel vehicles exhausts and FLT mainly from lightduty vehicles fuelled with gasohol. Globally, PAHs emissions from ethanol vehicles are on average 92\% lower than PAHs emissions from gasohol vehicles and low molecular weight PAHs are the dominant PAHs emitted from light-duty vehicles (Abrantes et al. 2009).

To evaluate human exposure to carcinogenic PAHs, the toxic equivalence factors (TEFs), mutagenic potency equivalent factors (MEFs) and the incremental lifetime cancer risk (ILCR) were calculated. The values of carcinogenic equivalents $\left(\mathrm{BaP}_{\mathrm{TEQ}}\right)$ for 8 PAHs varied from $0.001 \mathrm{mg} \mathrm{kg}^{-1}$ to $9.73 \mathrm{mg} \mathrm{kg}^{-1}$ with mean of $1.63 \mathrm{mg} \mathrm{kg}^{-1}$, while the value of mutagenic equivalents $\left(\mathrm{BaP}_{\mathrm{MEQ}}\right)$ ranged from $0.02 \mathrm{mg} \mathrm{kg}^{-1}$ to $5.08 \mathrm{mg} \mathrm{kg}^{-1}$ with mean of $0.62 \mathrm{mg} \mathrm{kg}^{-1}$. The highest and lowest values were obtained at P2 and P15 site, respectively. ICLR $_{\text {inhalation }}$ values ranged between $2.3810^{-13}$ and
$2.3210^{-10}$ with an average of $3.9010^{-11}$ for children and $1.5110^{-12}$ and $1.4710^{-9}$, with an average of 2.47 $10^{-10}$ for adults. ICLR $_{\text {dermal }}$ values ranged between $3.0610^{-8}$ and $2.9910^{-5}$ with an average of $5.0110^{-6}$ for children and $3.46 .10^{-8}$ and $3.3810^{-5}$, with an average of $5.6710^{-6}$ for adults. ICLR ingestion $_{\text {values }}$ ranged between $6.1610^{-7}$ and $6.0010^{-4}$ with an average of $1.0110^{-4}$ for children and $6.4610^{-7}$ and $1.5710^{-4}$, with an average of $1.9210^{-5}$ for adults. Higher values were found at P2 site, located at 200 $\mathrm{m}$ from the peripheral road and the main access avenue to the campus, and lower ones at P15 site, located at $1.6 \mathrm{~km}$ from peripheral road. Comparing our results with other studies, potential risk values are lower than values found in Beijing (Peng et al. 2011), Xi'an-China (Wang et al. 2018) and Turkey (Dumanoglu et al. 2017). Therefore, results showed that ILCR values for inhalation, dermal and ingestion showed very low $\left(\leq 10^{-6}\right)$ and low $(\leq$ $10^{-6}$ to $\left.<10^{-4}\right)$ potential cancer risk for adults and children.

\section{SPATIAL DISTRIBUTION AND SOURCE APPORTIONMENT COMBINING TRACE METALS AND PAHs}

The spatial distribution maps of trace metals and total PAHs concentrations were plotted using ArcGIS software and are presented in Figure 4. Dots correspond to concentration at sampling point and their size is proportional to the concentration value. Spatial distribution revealed that most of higher concentration of metals and PAHs are concentrated in the north and southeast part of the campus, in sampling sites (P1 to P6) closer to the peripheral road ("Marginal Pinheiros") and main entrance of the campus ( $\approx 150$ to $250 \mathrm{~m})$. P8, P9, P10, P13, P19 and P20 are located closed to avenue with higher slope and P7 and P16 close to a roundabout. $\mathrm{Sb}, \mathrm{V}$ and Mo do not show a clear pattern and are homogeneously distributed among the sampling sites. Geographic distribution of $\mathrm{Pb}$ and $\mathrm{Cu}$ is similar and $\mathrm{Ba}, \mathrm{PAHs}, \mathrm{Pt}, \mathrm{Pd}$ and $\mathrm{Zn}$ 


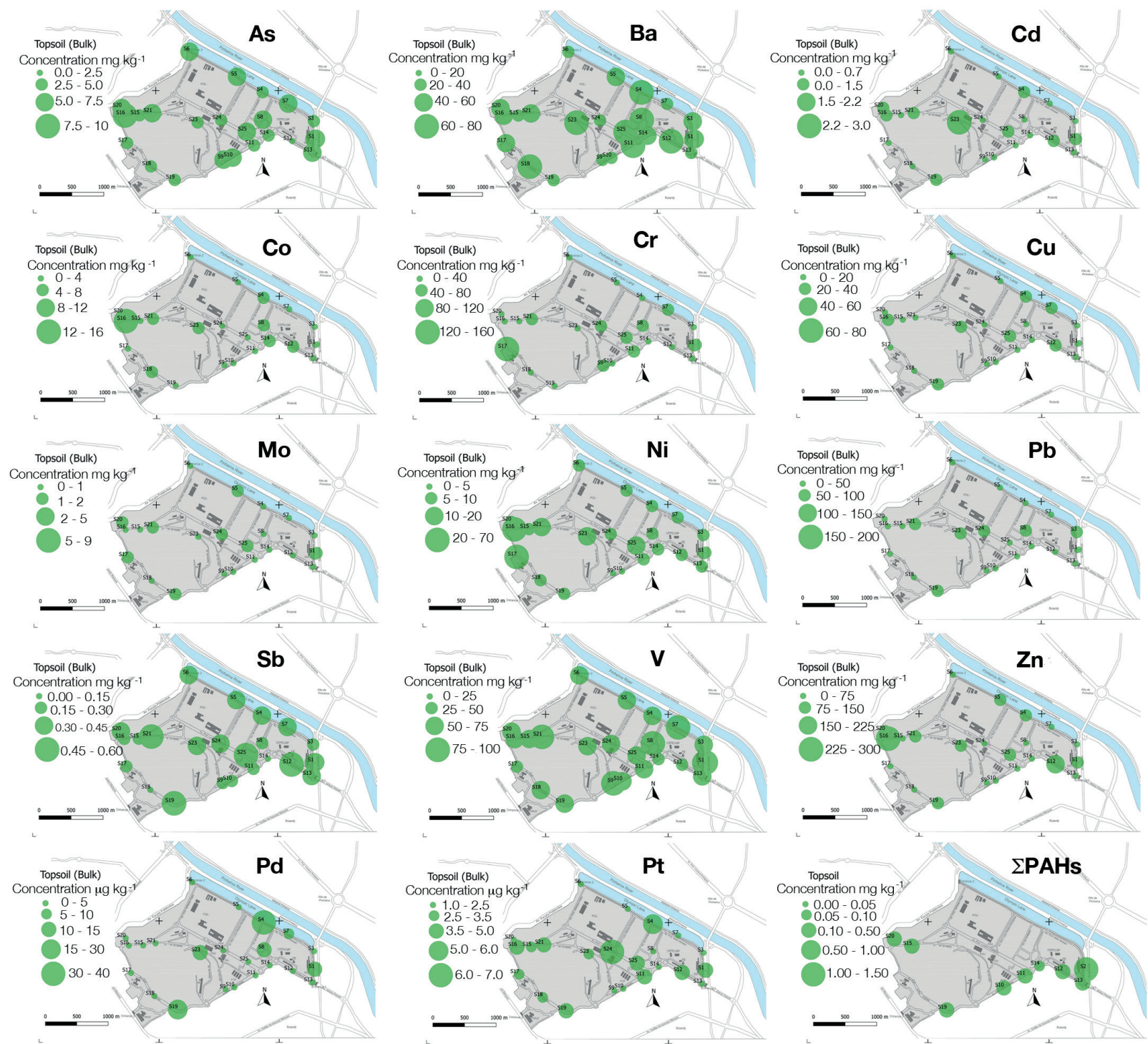

Figure 4 - Spatial distribution maps of trace metals and total PAHs concentrations in University campus in the São Paulo city.

concentrations seem to be grouped in the southeast part of the campus area and close to the Olympic streak.

The multivariate data analysis performed for elemental and PAHs concentrations, using the positive matrix factorization (PMF) model obtained four factors (Figure 5). In the first factor, ANT, BaA, CHRY, BbF, BkF, BghiP species were associated with $\mathrm{Pt}, \mathrm{K}$ and $\mathrm{Hg}$, which may be attributed to vehicular exhaust emissions. In the second factor, PHE and BbF were associated with $\mathrm{Co}, \mathrm{Ba}, \mathrm{Pd}, \mathrm{Pt}, \mathrm{Ca}, \mathrm{Mg}$ and $\mathrm{K}$, which may be associated with terrigeneous (natural soil contribution), traffic polluted dust resuspension and vehicular exhaust catalysts. Only heavy PAHs species were associated in the third factor (FLT, PYR, BkF, DBahA, BghiP), which may indicate diesel exhaust emissions adsorbed to dust. IND and most of metals are associated in the factor $4(\mathrm{As}, \mathrm{Cu}$, $\mathrm{Mo}, \mathrm{Pb}, \mathrm{Sb}, \mathrm{V}, \mathrm{Zn}, \mathrm{Cr}, \mathrm{Hg}$, Fe, Al, S, $\mathrm{SiO}_{2}$ ), which may be associated with brake source and traffic polluted dust resuspension. As discussed before, 

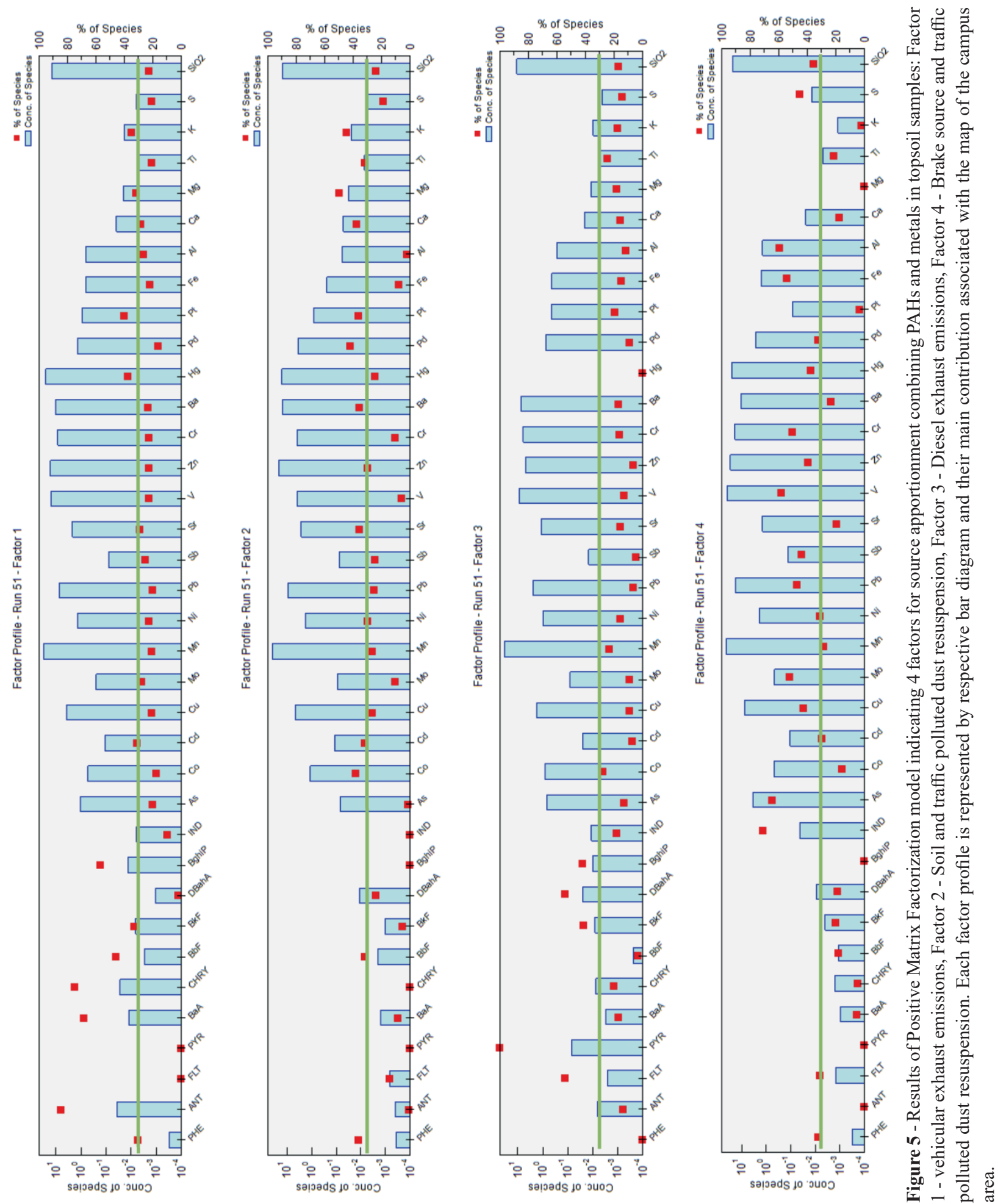


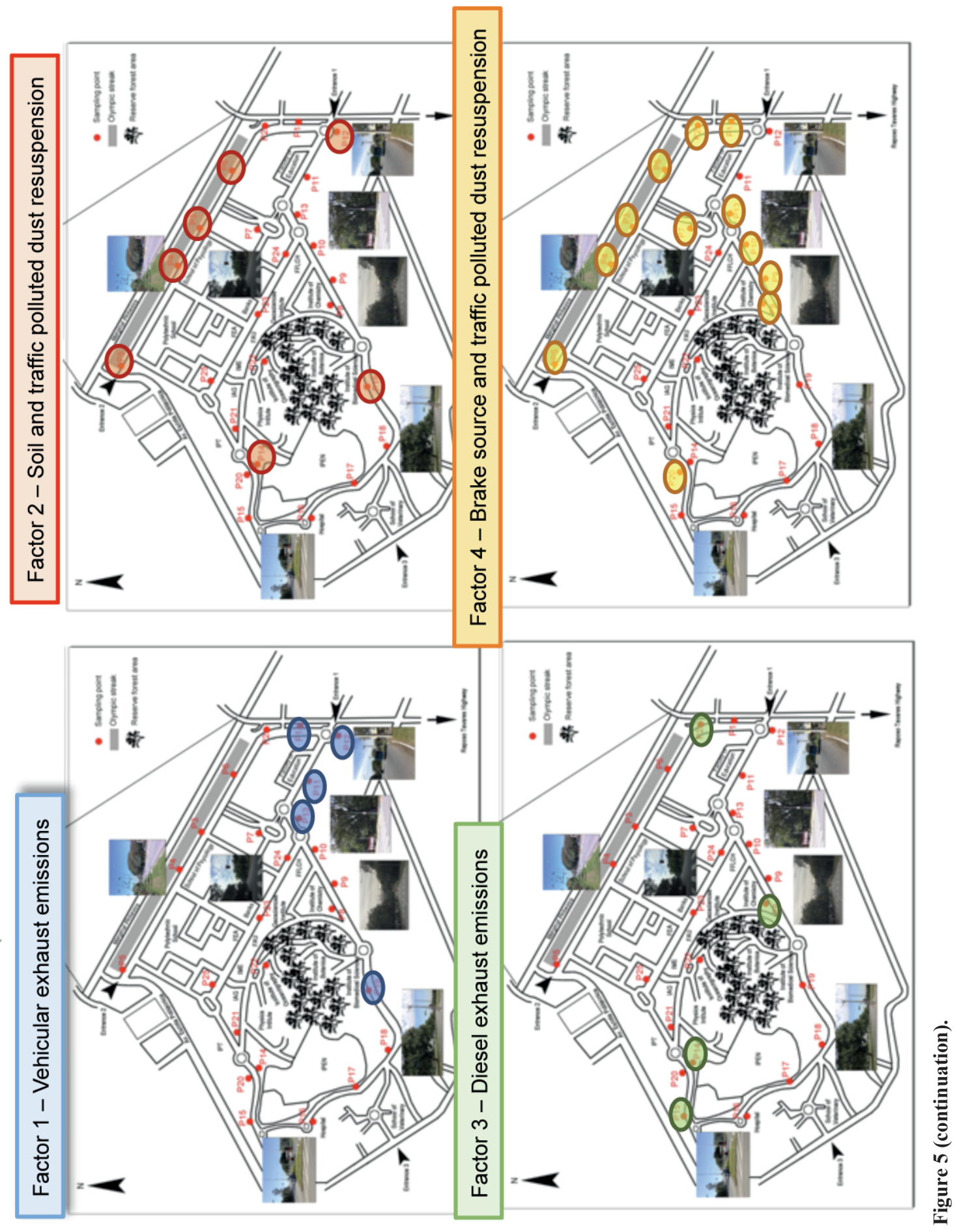


most of these elements are indicative of brake lining materials and road vehicle brake abrasion dust. Iijima et al. (2007) explained that potassium titanate is added to improve heat resistance and wear characteristics, $\mathrm{Cu}$ fiber and barium sulfate are usually used to improve control braking characteristics and braking abrasion generate fine particles $(<3 \mu \mathrm{m})$ that may be easily resuspended and deposited in adjacent road topsoils.

These factors clearly showed the contribution of traffic through vehicular exhaust emissions from the tail pipe but also non-exhaust emissions derived from road dust re-suspension and direct emissions from brakes, tires, discs pads and other vehicular components due to corrosion and abrasion.

It can also be observed that some trace metals and PAHs are more frequently higher in three main zones of the campus: near the university Hospital (and a roundabout); in the main avenue with higher slope and at the main entrance of the campus, that might be explained by traffic conditions and higher frequency of braking and acceleration also due to higher traffic during rush periods. De Silva et al. (2016) studied roadside soils of Melbourne and pointed out that vehicular speed, road age and traffic intensity are the main factors for metal accumulation in soils. Nearby the main entrances of the campus, the sampling points are close to high traffic avenues outside the campus and consequently higher traffic intensity. These zones of the campus are also surrounded by trees, which may promote a higher accumulation of litter on topsoil that may also accumulate more traffic related dusts. Finally, the main entrances are in a topographically lower area and consequently accumulate more soil and other particles by runoff during high rainy events.

\section{CONCLUSIONS}

The study showed that concentrations of metals are generally lower than the reference value established by CETESB and other studies carried out in the São Paulo urban area, except for Cd, Ni, $\mathrm{Pb}, \mathrm{Cr}$ and $\mathrm{Zn}$. PMF analysis allowed to identifying the vehicular sources for trace metals and PAHs. Traffic sources are related to both exhaust and non-exhaust emissions such as abrasion of brakes, tires, car components (Cu, Zn, Ba, Sb, Pt, Pd, Cr) and dust re-suspension with soil contribution. We also identified traffic intensity, predominant wind direction, vegetation cover and road slope as driver of spatial distribution of concentrations. Potential carcinogenic risk calculated for PAHs showed low and very low risk for human health neither for inhalation, ingestion or dermal contact routes.

\section{ACKNOWLEDGMENTS}

The authors wish to thank the Fundação de Amparo à Pesquisa do Estado de São Paulo (FAPESP) for the financial support of this research (Process $\mathrm{N}^{\circ}$ 2010/20835-1) and Jade Oliveira Butturi for her contribution to map plotting. We also thank the reviewers for their many helpful comments to improve the manuscript.

\section{AUTHOR CONTRIBUTIONS}

Christine Laure Marie Bourotte contributed to the sampling, and physical and chemical characterization of the samples and all results discussion. Lucy Elaine Sagauara and Mary Rosa Rodrigues de Marchi constributed to the quantification of PAHs in samples and results discussion.Carlos Eduardo Souto-Oliveira contributed to the statistical analysis by PMF and results discussion.

\section{REFERENCES}

ABRANTES R, DE ASSUNÇÃO VJ, PESQUERO CR, BRUNS RE AND NÓBREGA RP. 2009. Emission of polycyclic aromatic hydrocarbons from gasohol and ethanol vehicles. Atmos Environ 43: 648-654.

ADACHI K AND TAINOSHO Y. 2004. Characterization of heavy metal particles embedded in tire dust. Environ Int 30: 1009-1017. 
AGARWAL T. 2009. Concentration level, pattern and toxic potential of PAHs in traffic soil of Delhi, India. J Hazar Mater 171: 894-900.

ALEKSEENKO V AND ALEKSEENKO A. 2014. The abundances of chemical elements in urban soils. J Geochem Explor 147: 245-249.

ANDRADE S, ULBRICH HH, JANASI VA AND NAVARRO MS. 2009. The Determination of Total Hydrogen, Carbon, Nitrogen and Sulfur in Silicates, Silicate Rocks, Soils and Sediments. Geostand Geoanal Res 33: 337-345.

BORTEY-SAM N, IKENAKA Y, NAKAYAMA SMM, AKOTO O, YOHANNES YB, BAIDOO E, MIZUKAWA H AND ISHIZUKA M. 2014. Occurrence, distribution, sources and toxic potential of polycyclic aromatic hydrocarbons (PAHs) in surface soils from the Kumasi Metropolis, Ghana. Sci Total Environ 496: 471478.

BORUVKA L, VACEK O AND JEHLICKA J. 2005. Principal component analysis as a tool to indicate the origin of potentially toxic elements in soils. Geoderma 128: $289-300$

BOUROTTE C, FORTI MC, LUCAS Y AND MELFI AJ. 2009. Comparison of Polycyclic Aromatic Hydrocarbon (PAHs) concentrations in urban and natural forest soils in the Atlantic Forest (São Paulo State). An Acad Bras Cienc 81: 127-136.

BOUROTTE C, FORTI MC, TANIGUCHI S, BÍCEGO MC AND LOTUFO PA. 2005. A wintertime study of PAHs in fine and coarse aerosols in São Paulo city, Brazil. Atmos Environ 39: 3799-3811.

BRITO J, RIZZO LV, HERCKES P, VASCONCELLOS PC, CAUMO SES, FORNARO A, YNOUE RY, ARTAXO P AND ANDRADE MF. 2013. Physical-chemical characterisation of the particulate matter inside two road tunnels in the São Paulo Metropolitan Area. Atmos Chem Phys 13: 12199-12213.

BZDUSEK PA, LU J AND CHRISTENSEN ER. 2006. PCB congeners and dechlorination in sediments of Sheboygan River, Wisconsin, determined by matrix factorization. Environ Sci Technol 40: 120-129.

CACHADA A, PATO P, ROCHA-SANTOS T, DA SILVA EF AND DUARTE AC. 2012. Levels, sources and potential human health risks of organic pollutants in urban soils. Sci Total Environ 430: 184-192.

CAMPOS ML, PIERANGELI MAP, GUILHERME LRG, MARQUES JJ AND CURI N. 2003. Baseline Concentration of Heavy Metals in Brazilian Latosols. Commun Soil Sci Plant Anal 34: 547-557.

CANNON WF AND HORTON JD. 2009. Soil geochemical signature of urbanization and industrialization - Chicago, Illinois, USA. Appl Geochem 24: 1590-1601.
CETESB - COMPANHIA AMBIENTAL DO ESTADO DE SÃO PAULO. 2014. Relatório de qualidade do ar no Estado de São Paulo 2014, Report of air quality in the São Paulo State 2014. Cetesb, São Paulo.

CHARLESWORTH S, MIGUEL E AND DE ORDONEZ A. 2011. A review of the distribution of particulate trace elements in urban terrestrial environments and its application to considerations of risk. Environ Geochem Health 33: 103-123.

CHENG H, LI M, ZHAO C, LI K, PENG M, QIN A AND CHENG X. 2014. Overview of trace metals in the urban soil of 31 metropolises in China. J Geochem Explor 139: 31-52.

CHUNG MK, HU R, CHEUNG KC AND WONG MH. 2007. Pollutants in Hong Kong soils: Polycyclic aromatic hydrocarbons. Chemosphere 67: 464-473.

CICCHELlA D, DE VIVO B AND LIMA A. 2003. Palladium and platinum concentration in soils from the Napoli metropolitan area, Italy: Possible effects of catalytic exhausts. Sci Total Environ 308: 121-131.

COMERO S, VACCARO S, LOCORO G, DE CAPITANI L AND GAWLIK BM. 2014. Characterization of the Danube River sediments using the PMF multivariate approach. Chemosphere 95: 329-335.

DAVIS AP, SHOKOUHIAN M AND NI S. 2001. Loading estimates of lead, copper, cadmium, and zinc in urban runoff from specific sources. Chemosphere 44: 997-1009.

DE SILVA S, BALLAS, HUYNH T AND REICHMAN SM. 2016. Metal accumulation in roadside soil in Melbourne, Australia: Effect of road age, traffic density and vehicular speed. Environ Pollut 208: 102-109.

DETRAN - DEPARTAMENTO ESTADUAL DE TRÂNSITO DE SÃO PAULO. 2017. Frota de veículos em SP por tipo de veículo. Estatística de trânsito, Setembro 2017. Disponível em: https://www.detran.sp.gov.br/wps/wcm/ connect/portaldetran/detran/detran/EstatisticasTransito/.

DUMANOGLU Y, GAGA EO, GUNGORMUS E, SOFUOGLU SC AND ODABASI M. 2017. Spatial and seasonal variations, sources, air-soil exchange, and carcinogenic risk assessment for PAHs and PCBs in air and soil of Kutahya, Turkey, the province of thermal power plants. Sci Total Environ 580: 920-935.

FADIGAS FS, SOBRINHO NMBA, MAZUR N AND DOS ANJOS LHC. 2006. Estimation of reference values for cadmium, cobalt, chromium, copper, nickel, lead, and zinc in Brazilian soils. Commun Soil Sci Plant Anal 37: 945-959.

FIGUEIREDO AMG, TOCCHINI M AND DOS SANTOS ATFS. 2011. Metals in playground soils of São Paulo city, Brazil. Procedia Environ Sci 4: 303-309.

FUJITA CK. 2009. Hidrocarbonetos policíclicos aromáticos (HPAs) em solo: validação de método e avaliação da influência da queima de cana de açúcar na região de 
Araraquara. Dissertação de Mestrado, Instituto de Química, UNESP, Araraquara, 154 p. (Unpublished data).

FUJIWARA F, REBAGLIATI RJ, DAWIDOWSKI L, GÓMEZ D, POLLA G, PEREYRA V AND SMICHOWSKI P. 2011. Spatial and chemical patterns of size fractionated road dust collected in a megacitiy. Atmos Environ 45: 1497-1505.

GIOIA SMCL, BABINSKI M, WEISS DJ AND KERR AAFS. 2010. Insights into the dynamics and sources of atmospheric lead and particulate matter in São Paulo, Brazil, from high temporal resolution sampling. Atmos Res 98: 478-485.

GUAN Q, WANG F, XU C, PAN N, LIN J, ZHAO R, YANG Y AND LUO H. 2018. Source apportionment of heavy metals in agricultural soil based on PMF: A case study in Hexi Corridor, northwest China. Chemosphere 193: 189197.

HA VTL, HIEN NTT AND YONEDA M. 2016. Human health hazard of polycyclic aromatic hydrocarbon in road dust in Hanoi metropolis. J Sci Technol 54(2A): 27-34.

HAUGLAND T, OTTESEN RT AND VOLDEN T. 2008. Lead and polycyclic aromatic hydrocarbons (PAHs) in surface soil from day care centres in the city of Bergen, Norway. Environ Pollut 153: 266-272.

HE F, ZHANG Z, WAN Y, LU S, WANG L AND BU Q. 2009. Polycyclic aromatic hydrocarbons in soils of Beijing and Tianjin region: Vertical distribution, correlation with TOC and transport mechanism. J Environ Sci 21: 675-685.

IAG-USP - INSTITUTO DE ASTRONOMIA, GEOFÍSICA E CIÊNCIAS ATMOSFÉRICAS DA UNIVERSIDADE DE SÃO PAULO. 2016. Boletim Climatológico Anual da Estação Meteorológica do IAG/USP/ Seção Técnica de Serviços Meteorológicos. Instituto de Astronomia, Geofísica e Ciências Atmosféricas da Universidade de São Paulo 19, 2016 - São Paulo: IAG/USP, 2016.

IIJIMA A, SATO K, YANO K, TAGO H, KATO M, KIMURA H AND FURUTA N. 2007. Particle size and composition distribution analysis of automotive brake abrasion dusts for the evaluation of antimony sources of airborne particulate matter. Atmos Environ 41: 4908-4919.

IRITANI MA. 1993. Potencial hidrogeológico da Cidade Universitária de São Paulo. Dissertação de Mestrado. São Paulo: Instituto de Geociências, Universidade de São Paulo. (Unpublished data).

JENSEN H, REIMANN C, FINNE TE, OTTESEN RT AND ARNOLDUSSEN A. 2007. PAH-concentrations and compositions in the top $2 \mathrm{~cm}$ of forest soils along a 120 $\mathrm{km}$ long transect through agricultural areas, forests and the city of Oslo, Norway. Environ Pollut 145: 829-838.

JIANG YF, WANG XT, WANG F, JIA Y, WU MH, SHENG GY AND FU JM. 2009. Levels, composition profiles and sources of polycyclic aromatic hydrocarbons in urban soil of Shanghai, China. Chemosphere 75: 1112-1118.
JUNG KH, YAN B, CHILLRUD SN, PERERA FP, WHYATT R, CAMANN D, KINNEY PL AND MILLER RL. 2010. Assessment of Benzo(a)pyrene-equivalent carcinogenicity and mutagenicity of residential indoor versus outdoor Polycyclic Aromatic Hydrocarbons exposing young children in New York City. Inter J Environ Res Public Health 7(5): 1889-1900.

KABATA-PENDIAS A AND MUKHERJEE AB. 2007. Trace elements from soil to human, Trace Elements from Soil to Human. Springer Verlag Berlin Heidelberg Ed., $550 \mathrm{p}$.

KRAUSS M, WILCKE W, MARTIUS C, BANDEIRA AG, GARCIA MVB AND AMELUNG W. 2005. Atmospheric versus biological sources of polycyclic aromatic hydrocarbons (PAHs) in a tropical rain forest environment. Environ Pollut 135: 143-154.

KULKARNI P AND VENKATARAMAN C. 2000. Atmospheric polycyclic aromatic hydrocarbons in Mumbai, India. Atmos Environ 34: 2785-2790.

KWON HO AND CHOI SD. 2014. Polycyclic aromatic hydrocarbons (PAHs) in soils from a multi-industrial city, South Korea. Sci Total Environ 470-471: 1494-1501.

LEE CSL, LI X, SHI W, CHEUNG SCN AND THORNTON I. 2006. Metal contamination in urban, suburban, and country park soils of Hong Kong: A study based on GIS and multivariate statistics. Sci Total Environ 356: 45-61.

LICHT OAB. 2005. Geoquímica de solos do Estado do Paraná, vol 1/2, Mineropar, Curitiba, Paraná.

LIU S, XIA X, YANG L, SHEN M AND LIU R. 2010. Polycyclic aromatic hydrocarbons in urban soils of different land uses in Beijing, China: Distribution, sources and their correlation with the city's urbanization history. J Hazar Mater 177: 1085-1092.

LUO XS, YU S, ZHU YG AND LI XD. 2012. Trace metal contamination in urban soils of China. Sci Total Environ 421: 17-30.

MA J AND ZHOU Y. 2011. Soil pollution by polycyclic aromatic hydrocarbons: A comparison of two Chinese cities. J Environ Sci 23: 1518-1523.

MADRID F, DÍAZ-BARRIENTOS E AND MADRID L. 2008. Availability and bio-accessibility of metals in the clay fraction of urban soils of Sevilla. Environ Pollut 156: 605-610.

MADRID L, DÍAZ-BARRIENTOS E AND MADRID F. 2002. Distribution of heavy metal contents of urban soils in parks of Seville. Chemosphere 49: 1301-1308.

MANTA DS, ANGELONE M, BELLANCA A, NERI R AND SPROVIERI M. 2002. Heavy metals in urban soils: a case study from the city of Palermo (Sicily), Italy. Sci Total Environ 300: 229-243.

MASCLET P, BRESSON MA AND MOUVIER G. 1987. Polycyclic aromatic hydrocarbons emitted by power stations, and influence of combustion conditions. Fuel 66: 556-562. 
MCKENZIE ER, MONEY JE, GREEN PG AND YOUNG TM. 2009. Metals associated with stormwater-relevant brake and tire samples. Sci Total Environ 407: 5855-5860.

MIELKE HW, WANG G, GONZALES CR, LE B, QUACH VN AND MIELKE PW. 2001. PAH and metal mixtures in New Orleans soils and sediments. Sci Total Environ 281: 217-227.

MIELKE HW, WANG G, GONZALES CR, POWELL ET, LE B AND QUACH VN. 2004. PAHs and metals in the soils of inner-city and suburban New Orleans, Louisiana, USA. Environ Toxicol Pharmacol 18: 243-247.

MORCELLI CPR, FIGUEIREDO AMG, SARKIS JES, ENZWEILER J, KAKAZU M AND SIGOLO JB. 2005. PGEs and other traffic-related elements in roadside soils from São Paulo, Brazil. Sci Total Environ 345: 81-91.

MORILLO E, ROMERO AS, MAQUEDA C, MADRID L, AJMONE-MARSAN F, GRECMAN H, DAVIDSON CM, HURSTHOUSE AS AND VILLAVERDE J. 2007. Soil pollution by PAHs in urban soils: a comparison of three European cities. J Environ Monitori 9: 1001.

MORTON O, PUCHELT H, HERNÁNDEZ E AND LOUNEJEVA E. 2001. Traffic-related platinum group elements (PGE) in soils from Mexico City. J Geochem Explor 72: 223-227.

MOSTERT MMR, AYOKO GA AND KOKOT S. 2010. Application of chemometrics to analysis of soil pollutants. Trends Analyt Chem 29: 430-445.

MOTELAY-MASSEI A, OLLIVON D, GARBAN B, TEIL MJ, BLANCHARD M AND CHEVREUIL M. 2004. Distribution and spatial trends of PAHs and PCBs in soils in the Seine River basin, France. Chemosphere 55: 555565.

NADAL M, SCHUHMACHER M AND DOMINGO JL. 2004. Levels of PAHs in soil and vegetation samples from Tarragona County, Spain. Environ Pollut 132: 1-11.

NAMMOURA NETO GM, FIGUEIREDO AMG, RIBEIRO AP, SILVA NC, TICIANELLI RB AND CAMARGO SP. 2009. Metais em solos urbanos: avaliação da concentração em solos adjacentes à marginal do Rio Pinheiros. International Nuclear Atlantic Conference, INAC 2009, Rio de Janeiro, RJ, Brazil, September 27 to October 2, 2009.

NETTO ADP, KRAUSS TM, CUNHA IF AND REGO ECP. 2006. PAHs in SD: Polycyclic aromatic hydrocarbons levels in street dust in the central area of Niterói City, RJ, Brazil. Water Air Soil Pollut 176: 57-67.

ORECCHIO S. 2010. Assessment of polycyclic aromatic hydrocarbons (PAHs) in soil of a Natural Reserve (Isola delle Femmine) (Italy) located in front of a plant for the production of cement. J Hazard Mater 173: 358-368.

PENG C, CHEN W, LIAO X, WANG M, OUYANG Z, JIAO W AND BAI Y. 2011. Polycyclic aromatic hydrocarbons in urban soils of Beijing: Status, sources, distribution and potential risk. Environ Pollut 159: 802-808.

PENG C, OUYANG Z, WANG M, CHEN W AND JIAO W. 2012. Vegetative cover and PAHs accumulation in soils of urban green space. Environ Pollut 161: 36-42.

PENG C, OUYANG Z, WANG M, CHEN W, LI X AND CRITTENDEN JC. 2013. Assessing the combined risks of PAHs and metals in urban soils by urbanization indicators. Environ Pollut 178: 426-432.

PORSANI JL, BORGES WR, ELIS VR, DIOGO LA, HIODO FY, MARRANO A AND BIRELLI CA. 2004. Investigações geofísicas de superfície e de poço no Sítio Controlado de Geofísica Rasa do IAG-USP. Rev Bras Geof 22(3): 245-258.

QUIROZ W, CORTÉS M, ASTUDILLO F, BRAVO M, CERECEDA F, VIDAL V AND LOBOS MG. 2013. Antimony speciation in road dust and urban particulate matter in Valparaiso, Chile: Analytical and environmental considerations. Microchem J 110: 266-272.

RAY S, KHILLARE PS, AGARWAL T AND SHRIDHAR V. 2008. Assessment of PAHs in soil around the International Airport in Delhi, India. J Hazard Mater 156: 9-16.

REFF A, EBERLY SI AND BHAVE PV. 2007. Receptor Modeling of Ambient Particulate Matter Data Using Positive Matrix Factorization: Review of Existing Methods. J Air Waste Manag Assoc 57: 146-154.

REITH F, CAMPBELL SG, BALL AS, PRING A AND SOUTHAM G. 2014. Platinum in Earth surface environments. Earth Sci Rev 131: 1-21.

RIBEIRO AP, FIGUEIREDO AMG, SARKIS JES, HORTELLANI MA AND MARKERT B. 2012. First study on anthropogenic Pt, Pd, and Rh levels in soils from major avenues of São Paulo City, Brazil. Environ Monit Assess 184: 7373-7382.

RICCOMINI C AND COIMBRA AM. 1992. Geologia da Bacia Sedimentar. In: Ferreira AA, Alonso UR and Luz PL (Eds), Solos da cidade de São Paulo. São Paulo: ABMS/ ABEF.

STERNBECK J, SJÖDIN Å AND ANDRÉASSON K. 2002. Metal emissions from road traffic and the influence of resuspension - Results from two tunnel studies. Atmos Environ 36: 4735-4744.

SYED JH, IQBAL M, ZHONG G, KATSOIANNIS A, YADAV IC, LI J AND ZHANG G. 2017. Polycyclic aromatic hydrocarbons (PAHs) in Chinese forestsoils: pro le composition, spatial variations and source apportionment. Scientific Reports 7: 2692.

SZOLNOKI Z, FARSANG A AND PUSKÁS I. 2013. Cumulative impacts of human activities on urban garden soils: Origin and accumulation of metals. Environ Pollut 177: 106-115.

TANNER PA, MA HL AND YU PKN. 2008. Fingerprinting metals in urban street dust of Beijing, Shanghai, and Hong Kong. Environ Sci Technol 42: 7111-7117. 
THORPE A AND HARRISON RM. 2008. Sources and properties of non-exhaust particulate matter from road traffic: A review. Sci Total Environ 400: 270-282.

TOBISZEWSKI M AND NAMIEŚNIK J. 2012. PAH diagnostic ratios for the identification of pollution emission sources. Environ Pollut 162: 110-119.

UNITED NATIONS. 2014. Department of Economic and Social Affairs, Population Division. World Urbanization Prospects: The 2014 Revision, Highlights (ST/ESA/ SER.A/352).

VACCARO S, SOBIECKA E, CONTINI S, LOCORO G, FREE G AND GAWLIK BM. 2007. The application of positive matrix factorization in the analysis, characterization and detection of contaminated soils. Chemosphere 69: 1055-1063.

VANE CH, KIM AW, BERIRO DJ, CAVE MR, KNIGHTS K, MOSS-HAYES V AND NATHANAIL PC. 2014. Polycyclic aromatic hydrocarbons (PAH) and polychlorinated biphenyls (PCB) in urban soils of Greater London, UK. Appl Geochem 51: 303-314.

VARRICA D, BARDELLI F, DONGARRÀ G AND TAMBURO E. 2013. Speciation of $\mathrm{Sb}$ in airborne particulate matter, vehicle brake linings, and brake pad wear residues. Atmos Environ 64: 18-24.

VASCONCELLOS PC, ZACARIAS D, PIRES MAF, POOL CS AND CARVALHO LRF. 2003. Measurements of polycyclic aromatic hydrocarbons in airborne particles from the metropolitan area of São Paulo City, Brazil. Atmos Environ 37: 3009-3018.

WANG C, WU S, ZHOU SL, WANG H, LI B, CHEN H, YU Y AND SHI Y. 2015. Polycyclic aromatic hydrocarbons in soils from urban to rural areas in Nanjing: Concentration, source, spatial distribution, and potential human health risk. Sci Total Environ 527-528: 375-383.

WANG DG, YANG M, JIA HL, ZHOU L AND LI YF. 2009. Polycyclic sromatic hydrocarbons in urban street dust and surface soil: Comparisons of concentration, profile, and source. Arch Environ Contam Toxicol 56: 173-180.

WANG G, ZHANG Q, MA P, ROWDEN J, MIELKE HW, GONZALES C AND POWELL E. 2008. Sources and Distribution of Polycyclic Aromatic Hydrocarbons in Urban Soils: Case Studies of Detroit and New Orleans. Soil Sediment Contam 17: 547-563.

WANG L, ZHANG S, WANG L, SHI X, LU X, LI X AND LI X. 2018. Concentration and risk evaluation of Polycyclic Aromatic Hydrocarbons in urban soil in the typical semiarid city of Xi'an in northwest China. Inter J Environ Res Public Health 15: 607-622.

WANG XS. 2013. Assessment of heavy metal pollution in Xuzhou urban topsoils by magnetic susceptibility measurements. J Appl Geophys 92: 76-83.
WERKENTHIN M, KLUGE B AND WESSOLEK G. 2014. Metals in European roadside soils and soil solution - A review. Environ Pollut 189: 98-110.

WHITELEY JD AND MURRAY F. 2003. Anthropogenic platinum group element ( $\mathrm{Pt}, \mathrm{Pd}$ and $\mathrm{Rh}$ ) concentrations in road dusts and roadside soils from Perth, Western Australia. Sci Total Environ 317: 121-135.

WILCKE W. 2000. Polycyclic aromatic hydrocarbons (PAHs) in soil - a review. J Plant Nutr Soil Sc 163: 229-248.

WILCKE W. 2007. Global patterns of polycyclic aromatic hydrocarbons (PAHs) in soil. Geoderma 141: 157-166.

WILCKE W, AMELUNG W, KRAUSS M, MARTIUS C, BANDEIRA A AND GARCIA M. 2003. Polycyclic aromatic hydrocarbon (PAH) patterns in climatically different ecological zones of Brazil. Org Geochem 34: 1405-1417.

WILCKE W, BANDOWE BAM, LUESO MG, RUPPENTHAL M, DEL VALLE H AND OELMANN Y. 2014. Polycyclic aromatic hydrocarbons (PAHs) and their polar derivatives (oxygenated PAHs, azaarenes) in soils along a climosequence in Argentina. Sci Total Environ 473-474: 317-325.

WILCKE W, KRAUSS M AND AMELUNG W. 2002. Carbon isotope signature of polycyclic aromatic hydrocarbons (PAHs): Evidence for different sources in tropical and temperate environments? Environ Sci Technol 36: 3530-3535.

WILCKE W, LILIENFEIN J, LIMA SD AND ZECH W. 1999. Contamination of highly weathered urban soils in Uberlandia, Brazil. J Plant Nutr Soil Sc 162: 539-548.

WISEMAN CLS, HASSAN POUR Z AND ZEREINI F. 2016. Platinum group element and cerium concentrations in roadside environments in Toronto, Canada. Chemosphere 145: 61-67.

WISEMAN CLS AND ZEREINI F. 2009. Airborne particulate matter, platinum group elements and human health: a review of recent evidence. Sci Total Environ 407: 2493-2500.

WONG CSC, LI X AND THORNTON I. 2006. Urban environmental geochemistry of trace metals. Environ Pollut 142: 1-16.

YU W, LIU R, WANG J, XU F AND SHEN Z. 2015. Source apportionment of PAHs in surface sediments using positive matrix factorization combined with GIS for the estuarine area of the Yangtze River, China. Chemosphere 134: $263-$ 271.

ZHANG HB, LUO YM, WONG MH, ZHAO QG AND ZHANG GL. 2006. Distributions and Concentrations of PAHs in Hong Kong Soils. Environ Pollut 141: 107-114.

ZUO Q, DUAN YH, YANG Y, WANG XJ AND TAO S. 2007. Source apportionment of polycyclic aromatic hydrocarbons in surface soil in Tianjin, China. Environ Pollut 147: 303-310. 